\title{
Performance of Near Dry Hard Machining Through Pressurised Air Water Mixture Spray Impingement Cooling Environment
}

\author{
R. Kumar, A. K. Sahoo*, P. C. Mishra and R. K. Das \\ School of Mechanical Engineering, Kalinga Institute of Industrial Technology (KIIT), \\ Bhubaneswar-24, Odisha, India \\ *Email: aklala72@gmail.com
}

\begin{abstract}
The present paper emphasizes on experimental investigation, mathematical modelling, optimisation, tool life and cost analysis during machining of AISI D2 (heat treated) $(55 \pm 1$ HRC) steel using uncoated carbide tool through a novel method under spray impingement cooling environment. Taguchi based $\mathrm{L}_{16}$ orthogonal array was utilised to conduct the experiments. Analysis of variance with 95\% confidence level shows that the feed and depth of cut, are the most compelling factor towards surface roughness as well as chip reduction coefficient whereas cutting speed is the utmost compelling feature associated to flank wear as well as chip-tool interface temperature. Optimised result is identified as v1-f1-d1 (machining speed of $63 \mathrm{~m} / \mathrm{min}$; cutting feed of $0.04 \mathrm{~mm} / \mathrm{rev}$ and depth of cut of $0.1 \mathrm{~mm}$ ) based on grey relational analysis and tool life is found to be 15 minutes at optimised cutting conditions. Flank wear due to abrasion, catastrophic failure due to diffusion, chipping and notch wear are noticed as the major tool wear mechanisms in hard turning. Mathematical machinability models show statistically significance because due to the superior coefficient of correlations. As the global machining cost for each part is less, uncoated carbide tools can machine effectively, efficiently and economically at optimum cutting conditions under spray environment.
\end{abstract}

Keywords: Hard turning; spray impingement cooling; mathematical modelling; multiresponse optimisation; cost analysis.

\section{ABBREVIATION}

$\begin{array}{llll}\text { AISI } & \text { American Iron and Steel Institute } & \text { CVD } & \text { chemical vapor deposition } \\ \text { HRC } & \text { Rockwell hardness } & \text { VBc } & \text { flank wear at nose corner } \\ v & \text { cutting speed } & \mathrm{Ra} & \text { arithmetic surface roughness } \\ f & \text { feed } & \mathrm{T} & \text { chip-tool interface temperature } \\ d & \text { depth of cut } & \mathrm{PVD} & \text { physical vapor deposition } \\ \mathrm{A} & \text { air pressure } & \mathrm{P} & \text { probability of significance } \\ \mathrm{W} & \text { water pressure } & \mathrm{RSM} & \text { response surface methodology } \\ \mathrm{CBN} \text { cubic boron nitride } & \mathrm{CRC} & \text { chip reduction coefficient } \\ \mathrm{PCBN} \text { polycrystalline cubic boron nitride } & \mathrm{HMT} & \text { Hindustan machine tools } \\ \mathrm{MQL} \text { minimum quantity lubrication } & \mathrm{DF} & \text { degrees of freedom } \\ \mathrm{SIC} \text { spray impingement cooling } & \mathrm{SS} & \text { sum of squares } \\ \mathrm{MMC} \text { metal matrix composite } & \mathrm{MS} & \text { mean square } \\ \mathrm{TiN} & \text { titanium nitride } & \mathrm{F} & \text { variance ratio } \\ \mathrm{TiCN} & \text { titaniumcarbide nitride } & \mathrm{R}-\mathrm{Sq} \text { coefficient of determination } \\ \mathrm{Al}_{2} \mathrm{O}_{3} \text { aluminum oxide } & \mathrm{R}-\mathrm{Sq} \text { (adj) adjusted R-Sq }\end{array}$


TiAlN titanium aluminum nitride

AlCrN aluminum chromium nitride

SEM scanning electron microscopy

$\Phi \quad$ approach angle

$\mathrm{t}_{\mathrm{a}} \quad$ chip thickness after machining

$\mathrm{t}_{\mathrm{b}} \quad$ chip thickness before machining
ANOVA analysis of variance

Tc machining time

EDS energy dispersive spectroscopy

$\mathrm{C}$ overall machining cost

$\mathrm{T}_{1} \quad$ life of tool for single tip

$\mathrm{T}_{\mathrm{i}} \quad$ ideal time

\section{INTRODUCTION}

In recent years, turning on hardened steels beyond $50 \mathrm{HRC}$ with application of ceramic, CBN and PCBN cutting tools have been found significant and comparable with cylindrical grinding as far as surface quality is concerned. Now-a-days, researchers have been more attracted towards low cost tooling like uncoated and multilayer coated carbide tools due to economic feasibility. Application of carbide tools (uncoated and multi coated) are still unexplored to turn the hardened steels of hardness range 50-68 HRC. The performances of these tools are judged on the basis of work surface quality, tool wear, cutting forces, chip morphology etc. Hard turning has been mostly carried out in dry scenario as reported in the various literatures. Although dry machining is advantageous for finishing operation of hardened steel, but absence of cutting fluid promotes problem in chip disposal, generation of high temperature at chip- tool interface that leads to diffusion wear and large amount of friction between chip-tool and tool- work that creates higher abrasion wear and higher attrition.

However, the use of abundant coolant is advantageous of chip disposal, reduces frictions and reduces chip-tool interface temperature but it increases the cutting process cost and also not favourable to the health of human being. So, in recent years researchers have been more focused on use of near to dry machining or minimum quantity lubrication (MQL) where combination of pressurized air and oil used. Majority of researchers have compared the performance of various tools under dry, near dry (MQL) and wet surrounding in machining of steel at distinct hardness levels [1]. Spray impingement cooling (SIC) is also a kind of near to dry machining that comprises the mixture of pressurized air and water. Sahu et al. [2] reveled that with application of SIC system, the cutting performances were elevated relative to dry hard turning operation of 1015 grade steel using carbide insert.

Mishra et al. [3], experimentally showed that spray cooled environment produced better surface quality, reduced cutting tool temperature and improved productivity as contrasted to dry environment using uncoated carbide tool in machining MMCs. Sahoo and Sahoo [4] performed hard turning with cheaper tool like multi-layer coated (TiNTiCN-Al $\mathrm{O}_{3}$ - TiN) carbide tools in dry situation has been performed. From the performance analysis, wear mechanisms like abrasion and chipping were noticed in hard turning and the chip morphology analysis revealed a further encouraging machining situation in dry surrounding by coated (TiN) carbide tools. The grey based optimisation and response surface technique based mathematical modelling on wear at the surface of the flank face and work surface roughness during turning operation of AISI 4340 steel (heat-treated) with use of multi layered carbide tool during dry cutting scenario have been done. Tang et al. [5] explored the behavioural aspects of cutting input terms on temperature, shear angle and stress in orthogonal turning of D2 grade steel by CBN cutting tool. It was found that the highest temperature in the turned surface initially decreased and subsequently increased with augmentations of the depth of cut. 
Sahoo and Sahoo [6] performed comparative study of MTCVD multilayer coated $\left(\mathrm{TiN} / \mathrm{TiCN} / \mathrm{Al}_{2} \mathrm{O}_{3} / \mathrm{TiN}\right)$ with uncoated carbide insert on turning of AISI D2 steel $(22 \pm$ 1HRC) in dry cutting situation has been conducted and the growth wear zone for multilayer coated carbide cutting tool was uniform avoidance of any immature failure and abrasion was noticed to be principal mechanism of wear. Liew et al. [1] overviewed on the aspect of different cutting liquids and cooling methods during turning of hard steel. Various researchers work has emphasized based on different cutting conditions, tool materials, and machinability responses. It was also concluded that near dry/MQL can minimize the application of cutting fluid which leads to green environment comparing with flood turning. Mia and Dhar [7] study the consequences of material hardness of hardened steels and elevated pressure coolant over dry machining with respect to temperature and surface roughness. It was pointed out that the hardness of work material is mainly noteworthy factor for both temperature and roughness.

Gnanadurai and Varadarajan [8] perceived that under minimal fluid application using of heat pipe the diminished of machining temperature by $22 \%$ and wear on the tool surface by $15 \%$ respectively comparing with hard turning operation with fluid application without the support of heat pipe for removing the heat from the cutting insert. Kurnosov et al. [9] experimentally noticed the huge lessening in wear at tool surface and surface roughness using cooled ionized air into machining zone during turning operation. Sharma and Sidhu [10] experimentally studied and compared the diverse effects of dry and vegetable oil lubricant on turning of D2 steel by using a tungsten carbide tool. The comparative analysis disclosed that the machining under wet surrounding gave promising results over dry machining and enhanced the surface integrity, whereas the cutting temperature was lowered by almost 50\%. Agrawala et al. [11] reveled that roughness of the turned workpiece surface was extremely disturbed by the cutting feed succeeded by the machining speed and depth of cut during turning operation of hardened 4340 grade steel (up to $69 \mathrm{HRC}$ ) using CBN cutting tool under dry cutting.

Bouacha et al. [12] studied the combined outcomes of input turning variables and machining time on performance responses in turning operation of heat treated 52100 grade steel using CBN cutting inserts and the results indicated that the machining speed produced greater impact on abrasive wear of tool, while cutting forces were strongly affected by means of depth of cut. The machining time had a sizable effect on all cutting responses. Bartarya and Choudhury [13] performed ANOVA analysis which introduced that the depth of cut as well as machining feed was the highly compelling variables to influence the radial as well as cutting forces in turning whereas the roughness of machined workpiece surface was extremely influenced by depth of cut succeeded by cutting feed and speed.

Aouici et al. [14] studied that the radial depth of cut affected the machining force and feed force. The most favourable of work surface was produced at combination of smaller feed with maximum cutting speed. Khamel et al. [15] experimental findings showed that tool life of CBN tool was reduced by 59.14\%, $16.02 \%$ and $2.16 \%$ with 100 $\%$ increment of machining speed, cutting feed rate and depth of cut respectively and the average roughness of work surface was principally influenced by cutting feed succeeded by speed and depth of cut. Aouici et al. [16] revealed that the tool flank wear width of CBN insert improved with machining speed and cutting feed in turning of hardened steel X38CrMoV5-1 (50 HRC). Bouacha et al. [17] analysed the interaction between cutting factors and machining responses through the response surface methodology (RSM) and illustrated that the work surface roughness was mainly swayed by feed and cutting speed. Sahin [18] observed that the CBN cutting tool performed well compare to ceramic based 
cutting tool when turning hardened bearing steels and the percentage wise contributions of the cutting speed, cutting feed and hardness of tool on the tool life observed about $41.63,25.22$ and 32.68 respectively.

Rout et al. [19] studied erosion wear performance of polyester-GF-granite composite through Taguchi design of experiment. Optimal parameters have been suggested to yield minimum erosion wear rate. Dureja et al. [20] experimental analysis shows that abrasion wear was dominant when combination of cutting variables as low cutting speed, low cutting feed, and high work material hardness were taken in turning and the formation of adhesion wear occurred at high speed due to chemical interaction between the cutting tool and machined work-material whereas the built-up edges formed at moderate magnitudes of cutting speed. Yallese et al. [21] revealed that machining with CBN insert has a desirable wear resistance at relatively large-cutting speeds on hard turning of $100 \mathrm{Cr} 6$ steel and the optimal productivity was identified at $120 \mathrm{~m} / \mathrm{min}$ of cutting speed for an adequate flank wear width lower than $0.4 \mathrm{~mm}$. Kumar et al. [22] described that the feed rate was highly impactful for cutting temperature in turning of titanium alloy with use of PVD-applied coated carbide tool in dry situation.

Zinati and Razfar [23] introduced harmony search algorithm to evaluate the optimum level of cutting factorsand tool life along with operation time are investigated in turning process. Chinchanikar and Choudhary [24] experimentally performed higher value of cutting forces on turning of heat-treated steel and enhancement in tool life with coated (CVD) carbide tool and upgraded work surface quality was improved with PVD coated carbide tool. Shalaby et al. [25] examined the performance of three distinguish materials of cutting inserts (PCBN, TiN coated PCBN and mixed aluminum ceramic) during turning operation of heat-treated D2 grade tool steel (52 HRC). It was concluded that the ceramic tool was the best selection for turning the D2 grade tool steel with regard to the PCBN and TiN coated PCBN. Das et al. [26] related the machining performances of the coated cermet and uncoated carbide insert during turning of hardened steel AISI 4340 (48 HRC). The comparative results reported that the cermet tool executed superior than uncoated carbide in terms of work surface temperature, cutting force, and wear at flank surface. Jasni et al. [27] conducted experimental investigation on performance of multilayer coated (TiAlN/AlCrN) carbide tools in end milling operation of heat treated AISI D2 steel. Flank wear, tool breakage and chipping at machining tip were identified as the main factors for tool failure of cutting inset.

Dosbaeva et al. [28] studied the performance of CVD multilayer $\mathrm{TiCN} / \mathrm{Al}_{2} \mathrm{O}_{3}$ coated tungsten-carbide inserts to low content of PCBN inserts during hard turning of heat-treated D2 (52 HRC) grade tool steel. The life of the coated carbide tool was 3.3 times more than PCBN tool at machining speed of $60 \mathrm{~m} / \mathrm{min}$ but at machining speed of $175 \mathrm{~m} / \mathrm{min}$, PCBN performed better with higher tool life as compare to coated tungsten carbide due to its higher hot hardness. Mhamdi et al. [29] worked on turning operation of hardened D2 steel and proposed that the chip formation was swayed by cutting conditions and the micro hardness of the chip is altered due to microstructural transformations attributable to the exploit of the insert and cutting conditions. Najiha and Rahman [30] optimised the process parameters during end milling of aluminium alloy through response surface methodology under MQL environment using TiAlN coated carbide cutting tool and good machinability is observed. Sahid et al. [31] studied the end milling performance of aluminium alloy under MQL condition through coated carbide and proved to be economical benefits and better machinability. According to Gajrani et al, tungsten carbide tool (coated flank face and uncoated rake face) performed better under Minimum quantity cutting fluid relative to dry and flood cooling condition as lower coefficient of friction, 
cutting forces and surface roughness were noticed under minimum quantity cutting fluid [32].

Hardened D2 steel offers excellent wear and abrasion resistance, due to presence of large quantities of carbides in the microstructure. D2 steel has variety of applications in tool-press manufacturing industries, molds and dies manufacturing industries, automobile industries, electronic industries etc., but it is considered as a difficult to turn metal. So, an investigation of optimal machining conditions for machining of D2 steels are highly needful. Hence, in the present work it has been selected as work material to investigate their machinability.

Established on the literature studied, hard turning of AISI D2 steel were extensively machined with polycrystalline cubic boron nitride (PCBN), cubic boron nitride $(\mathrm{CBN})$ and ceramic cutting tools under dry environment. Again, hard turning operation of D2 steel at elevated hardness above 55 HRC using low cost uncoated carbide insert is rarely investigated and lacking as far as literature studies are concerned and will be essentially worthwhile for research to improve its performance. Also, application of spray impingement cooling (SIC) on uncoated carbide tool performance in hard turning of AISI D2 steel is rarely seen in the literature and found the gap in research. Thus, extensive investigations on machinability performance of uncoated carbide tool during turning of hardened D2 steel under SIC conditions leads to near dry machining will definitely be valuable for machining industries point of view. This is the novelty of the present research which has been extensively investigated with respect to roughness of machined surface, wear at flank surface, chip-tool contact temperature, chip morphology, chip reduction coefficient tool life and machining cost evaluation. This gives the insight of its applicability in hard turning applications.

\section{EXPERIMENTAL PROCEDURE}

The principal goal of the current study is to investigate the cutting performance of uncoated carbide insert on hard turning operation of AISI D2 steel (high chromium and high carbon) round shape bar with dia. of $48 \mathrm{~mm}$ and length $200 \mathrm{~mm}$ in spray impingement cooling situation. Taguchi $\mathrm{L}_{16}$ orthogonal array is selected to conduct the experiments on HMT (NH22) precision lathe of $11 \mathrm{~kW}$ power capacity and the speed of the spindle varies in between 40 to $2040 \mathrm{rpm}$. Uncoated carbide cutting tool of WIDIA make with ISO designation CNMG 120408 (TTR with P-grade) is utilized for this experimental work. The insert has negative rake angle $-6^{\circ}$, approach angle $95^{\circ}$ and nose radius of $0.8 \mathrm{~mm}$. The tool is tightly screwed on a WIDIA make tool holder of ISO designation PCLNR 2525 M12. The hardness of specimen has been improved to $(55 \pm 1)$ HRC using conventional heat treatment process followed by oil quenching. Initially, the test specimens were heated slowly and uniformly up to $700^{\circ} \mathrm{C}$ and then rapidly heat till $930^{\circ} \mathrm{C}$ and allow it to equalize. Further, the specimens were placed into Servo oil for quenching. Again, the specimens were heated uniformly up to $400^{\circ} \mathrm{C}$ and hold for 30 minutes and then kept it to cool at surrounding temperature.

The entire experiments have been conducted in spray impingement cooling environment on the basis of five machining parameters namely machining speed $(\mathrm{m} / \mathrm{min})$, cutting feed $(\mathrm{mm} / \mathrm{rev})$, depth of cut $(\mathrm{mm})$, air pressure (bar) and water pressure (bar). The spray cooling has been carried by the internal mixing air blast nozzle where pressurized air and water mixed together. Sahu et al. [2] found the optimum result during hard turning at air pressure $(1.5$ bar) and water pressure $(1$ bar) and these conditions was fixed and chosen for entire set of experiments. The other input variables like machining speed, feed 
and depth of cut have four levels as reported in Table 1. The schematic view of process outlines is listed in Figure 1.

Table 1. Turning test details.

\begin{tabular}{ll}
\hline Turning conditions & Descriptions \\
\hline Machine tool & HMT lathe, NH-22 \\
Test specimen & AISI D2 steel (55 \pm 1 HRC) \\
Test specimen dimension & $\varnothing 48 \mathrm{~mm} \times 200 \mathrm{~mm}$ \\
Cutting inserts & CNMG120408 (WIDIA) \\
& Uncoated carbide (TTR with P grade) \\
Tool holder & PCLNR 2525 M12 \\
Machining parameters & 4 levels of factors \\
Depth of cut (d), mm & $0.1,0.2,0.3,0.4$ \\
Feed rate (f), mm/rev & $0.04,0.08,0.12,0.16$ \\
Cutting speed (v), m/min & $63,108,140,182$ \\
Air pressure (bar) & 1.5 (constant) [2] \\
Water pressure (bar) & 1.0 (constant) [2] \\
Cooling environment & spray impingement cooling \\
& (pressurised air and water mixture) \\
\hline
\end{tabular}

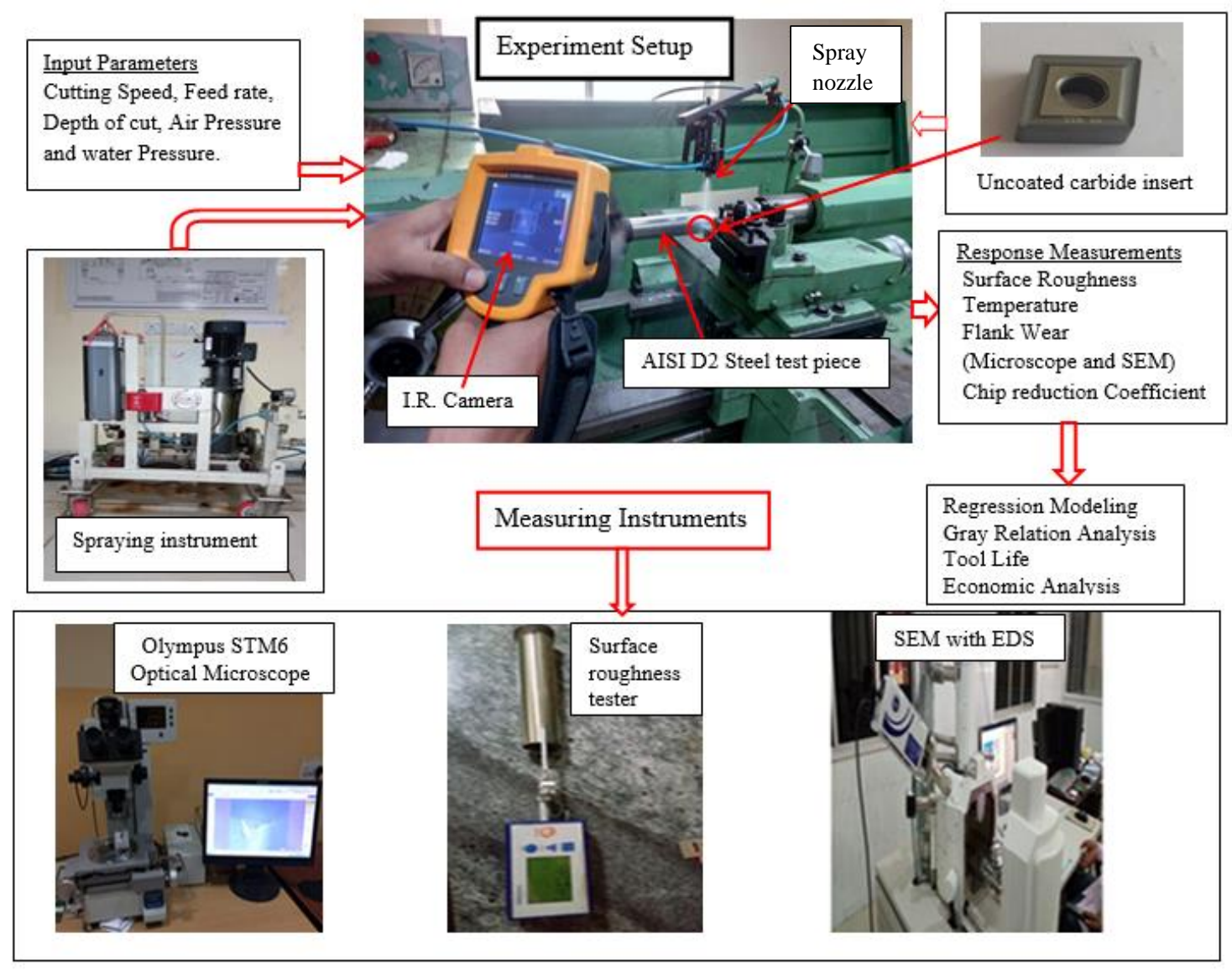

Figure 1. Experimentation details with process outline. 
The present work emphasises the machinability measure factors like surface roughness, chip-tool interface temperature, flank wear, chip morphology during hard turning. Taylor Hobson (Sutronic 25) surface roughness measuring device has been calibrated before measurement of surface roughness. The mean surface roughness ( $\mathrm{Ra})$ was measured at five various locations at the turned surface of test workpiece and its mean value is considered. Thermal camera (FLUKE Ti32) utilised to measure the temperature at chip-tool contact point is during machining as shown in Figure 1.

The emissivity taken for temperature measurement is 0.82 [33]. The temperature measurement range of thermal camera is $-20{ }^{\circ} \mathrm{C}$ to $+600{ }^{\circ} \mathrm{C}$ whereas measurement accuracy is $\pm 2{ }^{\circ} \mathrm{C}$ or $2 \%$ (at $25^{\circ} \mathrm{C}$ nominal, whichever is greater). The thermal sensitivity is $\leq 0.045^{\circ} \mathrm{C}$ and the camera response time is $200 \mathrm{~ms}$. The highest temperature at chiptool interface zone has been considered for analysis. The flank wear and chips imageries are trapped by Olympus STM6 optical microscope with Olympus SC30 camera utilizing 50x and 30x magnification. Width of the flank wear and thickness of the chip for calculating chip reduction coefficient (CRC) are measured using Olympus stream basic software and digital caliper respective and displayed are shown in Figure1. The tool life is calculated on standard tool flank wear (VBc) standards of $0.3 \mathrm{~mm} \mathrm{[34].}$

\section{RESULTS OF MORPHOLOGY}

The experimental result of surface roughness (Ra), cutting temperature $(\mathrm{T})$, flank wear (VBc) and chip morphology for $\mathrm{L}_{16}$ design data set is given in Table 2.

\section{Aspects of Surface Roughness}

The principal target of any manufacturers is to achieve better surface quality with higher productivity rate at low cost. Since few years, researchers are trying to use low cost tool in hard machining without sacrificing the surface quality of the product. Hence analysis of surface roughness at different cutting conditions is highly needful in finish turning of difficult to cut material. The present work carried under spray impingement cooling environment where high pressure and high velocity of cutting fluid supplied which penetrates cutting zone easily by capillary action that leads to the reduction of friction between tool-chip and tool - workpiece. However, in most of the turning tests (Table 2), the arithmetic surface roughness value is found to be lower than the recommended roughness limit of 1.6 micron except at highest feed $0.16 \mathrm{~mm} / \mathrm{rev}$ with highest depth of cut $0.4 \mathrm{~mm}$ and lowest machining speed $63 \mathrm{~m} / \mathrm{min}$ cutting condition. In the hence for surface roughness concern, the uncoated carbide tool performed well under the considered parametric conditions.

Surface roughness investigation is primarily based upon evaluation of surface characteristics which is represented by surface topography of turned surface. Surface topography in this study is represented by maximal and minimal distances between the groves lines formed upon the turned surface due to the feed rate. Surface topography of discrete trails was illustrated in Figure 2. In Figure 2(a) very close grooves lines are noticed on the turned surface which is result of machining with most minimal feed of $(0.04 \mathrm{~mm} / \mathrm{rev})$, while Figure 2(b) represent more wider groove line as it was machined with $(0.08 \mathrm{~mm} / \mathrm{rev})$ feed, when compared with Figure 2(a) which has the most minimal feed value. In Figure 2(c), even more, wider grooves line is noticed compared to both previous figures, due to its high feed value of $(0.12 \mathrm{~mm} / \mathrm{rev})$. The maximum widest groove lines are noticed in Figure 2(d) which are turned at maximum feed value of $(0.16$ 
$\mathrm{mm} / \mathrm{rev}$ ). Machining with maximum feed values presents wider groves lines, while proximal groove lines were noticed with minimal feed values. As a result, a higher surface roughness is noticed with maximum feed rate which indicates wider groove lines and the turned surface with proximal groove line represent lower surface roughness as it was turned with lower feed rate. Due to application of spray (air-water mixture) oxidation on turned surface took place as noticed in Figure 2. Oxidation accelerates with improving speed and feed which is confirmed by the Figure 2(a) to (d) as density of corrosive marks increases with speed and feed.

Table 2. Turning test results.

\begin{tabular}{|c|c|c|c|c|c|c|c|c|c|}
\hline Run & $\begin{array}{c}\mathrm{d} \\
(\mathrm{mm})\end{array}$ & $\begin{array}{c}\mathrm{f} \\
(\mathrm{mm} / \mathrm{rev})\end{array}$ & $\begin{array}{c}\mathrm{v} \\
(\mathrm{m} / \mathrm{min})\end{array}$ & $\begin{array}{c}\mathrm{Ra} \\
(\mu \mathrm{m})\end{array}$ & $\begin{array}{c}\mathrm{T} \\
\left({ }^{\circ} \mathrm{C}\right)\end{array}$ & $\begin{array}{l}\mathrm{VBc} \\
(\mathrm{mm})\end{array}$ & Colour & Shape & CRC \\
\hline 1 & 0.1 & 0.04 & 63 & 0.568 & 141 & 0.182 & Metallic & $\begin{array}{l}\text { Helical\& } \\
\text { Saw tooth }\end{array}$ & 1.907 \\
\hline 2 & 0.1 & 0.08 & 108 & 0.674 & 164.4 & 0.745 & Metallic & $\begin{array}{l}\text { Ribbon\& } \\
\text { Saw tooth }\end{array}$ & 1.731 \\
\hline 3 & 0.1 & 0.12 & 140 & 0.936 & 180.9 & 1 & Metallic & $\begin{array}{l}\text { Ribbon \& } \\
\text { Saw tooth }\end{array}$ & 1.606 \\
\hline 4 & 0.1 & 0.16 & 182 & 1.302 & 204.7 & 1.05 & $\begin{array}{l}\text { Burnt } \\
\text { Blue }\end{array}$ & $\begin{array}{l}\text { Ribbon\& } \\
\text { Saw tooth }\end{array}$ & 1.581 \\
\hline 5 & 0.2 & 0.04 & 108 & 0.626 & 174.9 & 0.886 & Blue & $\begin{array}{l}\text { Helical \& } \\
\text { Saw tooth }\end{array}$ & 1.957 \\
\hline 6 & 0.2 & 0.08 & 63 & 0.812 & 178.6 & 0.258 & Blue & $\begin{array}{l}\text { Ribbon\& } \\
\text { Saw tooth }\end{array}$ & 1.832 \\
\hline 7 & 0.2 & 0.12 & 182 & 0.966 & 214.2 & 1.21 & $\begin{array}{l}\text { Burnt } \\
\text { blue }\end{array}$ & $\begin{array}{l}\text { Ribbon \& } \\
\text { Saw tooth }\end{array}$ & 1.689 \\
\hline 8 & 0.2 & 0.16 & 140 & 1.422 & 192.4 & 1.082 & $\begin{array}{l}\text { Burnt } \\
\text { blue }\end{array}$ & $\begin{array}{l}\text { Spiral c \& } 8 \\
\text { type \& Saw } \\
\text { tooth }\end{array}$ & 1.706 \\
\hline 9 & 0.3 & 0.04 & 140 & 0.876 & 197.9 & 1.184 & Blue & $\begin{array}{l}\text { Helical\& } \\
\text { Saw tooth }\end{array}$ & 2.057 \\
\hline 10 & 0.3 & 0.08 & 182 & 0.944 & 223.5 & 1.4 & $\begin{array}{l}\text { Burnt } \\
\text { blue }\end{array}$ & $\begin{array}{l}\text { Long snarl \& } \\
\text { Saw tooth }\end{array}$ & 1.932 \\
\hline 11 & 0.3 & 0.12 & 63 & 1.204 & 181.1 & 0.448 & $\begin{array}{l}\text { Partial } \\
\text { blue }\end{array}$ & $\begin{array}{l}\text { Helical \& } \\
\text { Saw tooth }\end{array}$ & 1.907 \\
\hline 12 & 0.3 & 0.16 & 108 & 1.524 & 187.6 & 0.974 & $\begin{array}{l}\text { Partial } \\
\text { blue }\end{array}$ & $\begin{array}{l}\text { Helical \& } \\
\text { Saw tooth }\end{array}$ & 1.894 \\
\hline 13 & 0.4 & 0.04 & 182 & 1.152 & 229 & 1.724 & $\begin{array}{l}\text { Burnt } \\
\text { blue }\end{array}$ & $\begin{array}{l}\text { Long snarl \& } \\
\text { Saw tooth }\end{array}$ & 2.108 \\
\hline 14 & 0.4 & 0.08 & 140 & 1.07 & 208.6 & 1.275 & $\begin{array}{l}\text { Burnt } \\
\text { blue }\end{array}$ & $\begin{array}{l}\text { Ribbon \& } \\
\text { Saw tooth }\end{array}$ & 2.083 \\
\hline 15 & 0.4 & 0.12 & 108 & 1.264 & 181.4 & 0.924 & Blue & $\begin{array}{l}\text { Helical \& } \\
\text { Saw tooth }\end{array}$ & 2.024 \\
\hline 16 & 0.4 & 0.16 & 63 & 1.696 & 169.2 & 0.536 & Blue & $\begin{array}{l}\text { Helical \& } \\
\text { Saw tooth }\end{array}$ & 2.032 \\
\hline
\end{tabular}



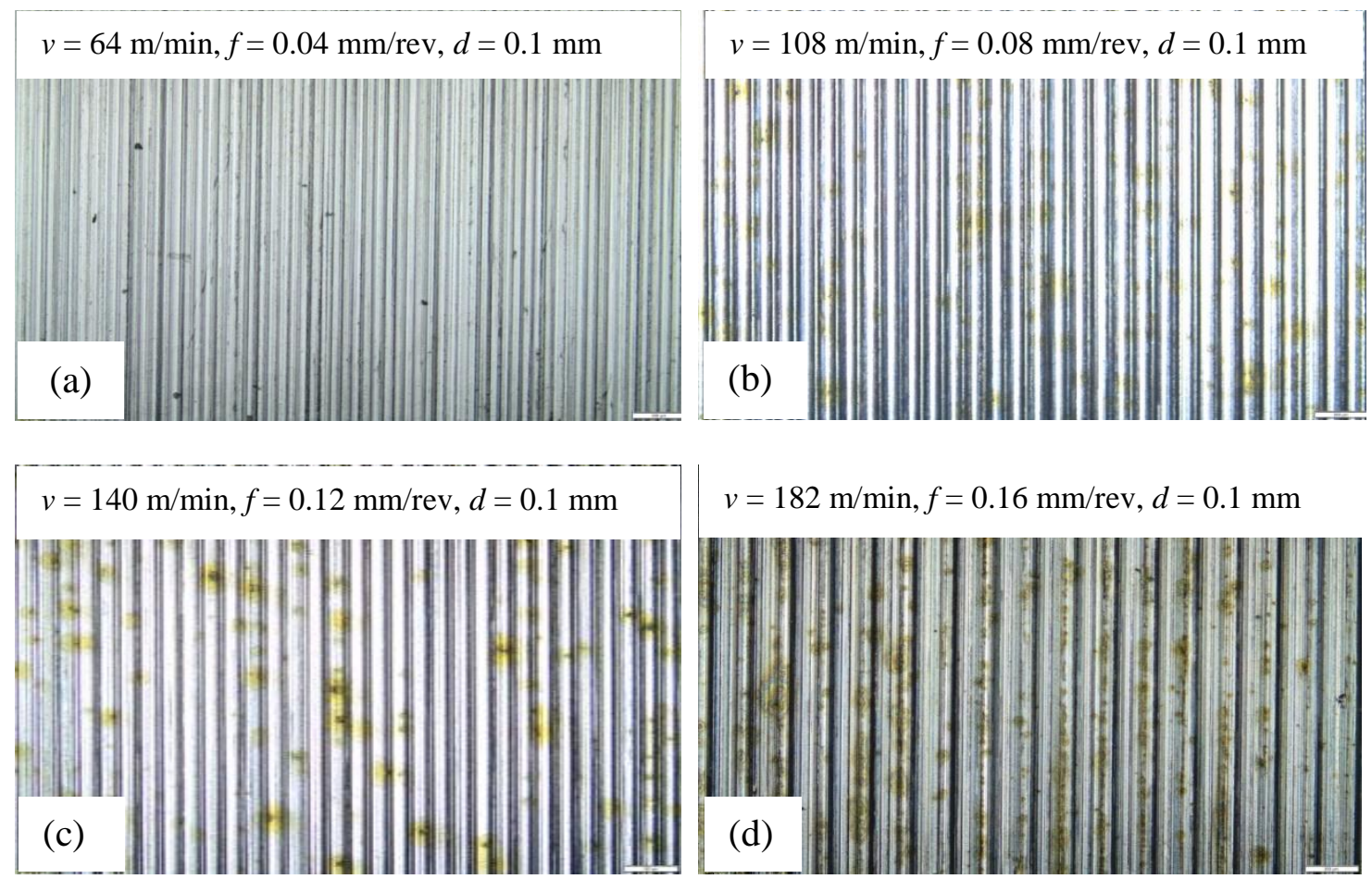

$v=182 \mathrm{~m} / \mathrm{min}, f=0.16 \mathrm{~mm} / \mathrm{rev}, d=0.1 \mathrm{~mm}$

Figure 2. Surface topology of turned surface at (a) Run 1 (b) Run 2 (c) Run 3 and; (d) Run 4.

From graphical presentation in Figure 3, surface roughness is increasing gradually with improving feed and depth of cut whereas variation in speed is not relevant for surface roughness. In Table 3 it has been noticed that for the surface roughness depth of cut and feed rate are the supreme relevant aspect for surface roughness, whereas the speed of cutting is not significant. Agrawala et al. [11] and Khamel et al. [15] also examined that cutting feed predominant factor to influence the surface roughness then the machining speed and radial depth of cut during cutting of hardened steel.

Fitted Means

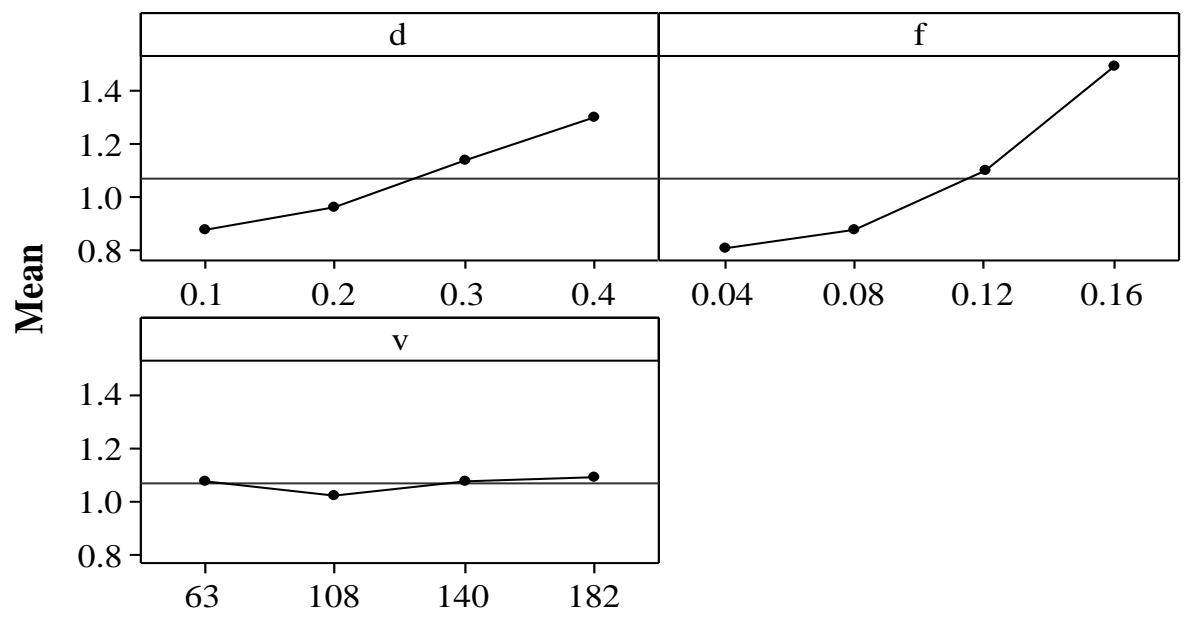

Figure 3. Graphical plot for surface roughness. 
Table 3. ANOVA for surface roughness.

\begin{tabular}{lccccccc}
\hline Source & DF & Seq SS & Adj SS & Adj MS & F & P & Remarks \\
\hline $\mathrm{d}$ & 3 & 0.43244 & 0.43245 & 0.14415 & 36.77 & 0.000 & Significant \\
$\mathrm{f}$ & 3 & 1.12575 & 1.12575 & 0.37525 & 95.72 & 0.000 & Significant \\
$\mathrm{v}$ & 3 & 0.01068 & 0.01068 & 0.00356 & 0.91 & 0.491 & Insignificant \\
Error & 6 & 0.02352 & 0.02352 & 0.00392 & & & \\
Total & 15 & 1.59240 & & & & & \\
$\mathrm{~S}=0.0626126$ & \multicolumn{2}{c}{$\mathrm{R}^{2}=98.52 \%$} & $\mathrm{R}^{2}(\operatorname{adj})=96.31 \%$ & & \\
\hline
\end{tabular}

\section{Aspects of Cutting Temperature}

At chip-tool contact point cutting temperature performs a imperative role in finish hard turning operations. The rubbing action among chip-tool and tool-work promotes the frictions that enhanced the higher heat generation at the cutting zone. Though the material is easy to cut as workpiece gets soften due to rise of cutting temperature, at the same time the tool deformed plastically and accelerates wear. Hence on this conflicting aspect, researchers are more interested to lowering the temperature at significant level impinging minute amount of lubricant at tool-work interface so as to get near dry machining. Therefore, spray impingement cooling system is applied to get better performance of tools as high pressure and high velocity fluid reduces the friction between chip-tool interfaces. Highest cutting temperature was reported (Table 2$)$ at elevated cutting speeds $(182 \mathrm{~m} / \mathrm{min}$ and $140 \mathrm{~m} / \mathrm{min}$ ). The cutting temperature improves with improving machining speed and depth of cut. Figure 4 displays the measured thermal images at different cutting conditions. From Table 2 and Figure 4 (d), the maximum cutting temperature generated among all runs is $229^{\circ} \mathrm{C}$, that clearly state that the use of spray cooling system can reduce the cutting temperature at chip-tool contact point.

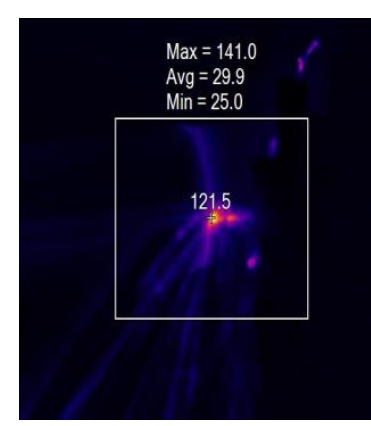

(a)

$d=0.1 \mathrm{~mm}$

$f=0.04 \mathrm{~mm} / \mathrm{rev}$

$v=63 \mathrm{~m} / \mathrm{min}$

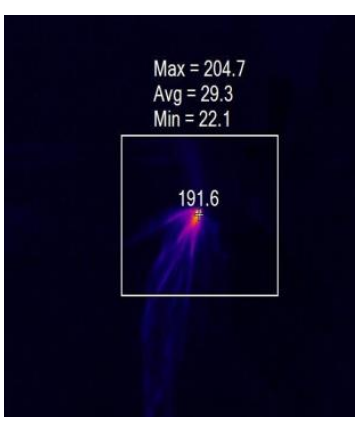

(b)

$d=0.1 \mathrm{~mm}$

$f=0.16 \mathrm{~mm} / \mathrm{rev}$

$v=182 \mathrm{~m} / \mathrm{min}$

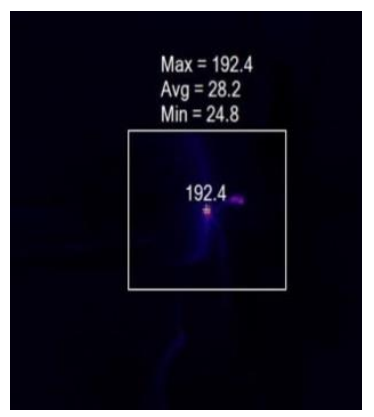

(c)

$d=0.2 \mathrm{~mm}$

$f=0.16 \mathrm{~mm} / \mathrm{rev}$

$v=140 \mathrm{~m} / \mathrm{min}$

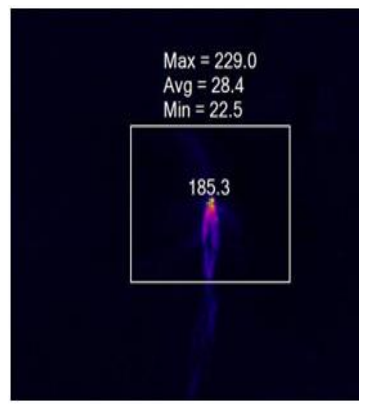

(d)

$d=0.4 \mathrm{~mm}$

$f=0.04 \mathrm{~mm} / \mathrm{rev}$

$v=182 \mathrm{~m} / \mathrm{min}$

Figure 4. Thermal images of cutting temperatures at (a) Run 1 (b) Run 4 (c) Run 8 and; (d) Run 13.

Graphical plot in Figure 5 introduced that the temperature rises with speed as well as depth of cut but rate of increment in temperature due to rise in depth of cut is quite low compare to rising speed. Further, feed doesn't affect more as it varies along mean line. ANOVA results in Table 4 revealed that the speed, as well as depth of cut, are the mainly noteworthy terms for cutting temperature as the $p$ value for both factors are seen to be 
lower than 0.05 whereas feed is insignificant as the $\mathrm{p}$ value is more than the 0.05 . Cutting speed is highly significant for cutting temperature succeeded by depth of cut. Similar finding has been reported by Tang et al. [5].

\section{Fitted Means}

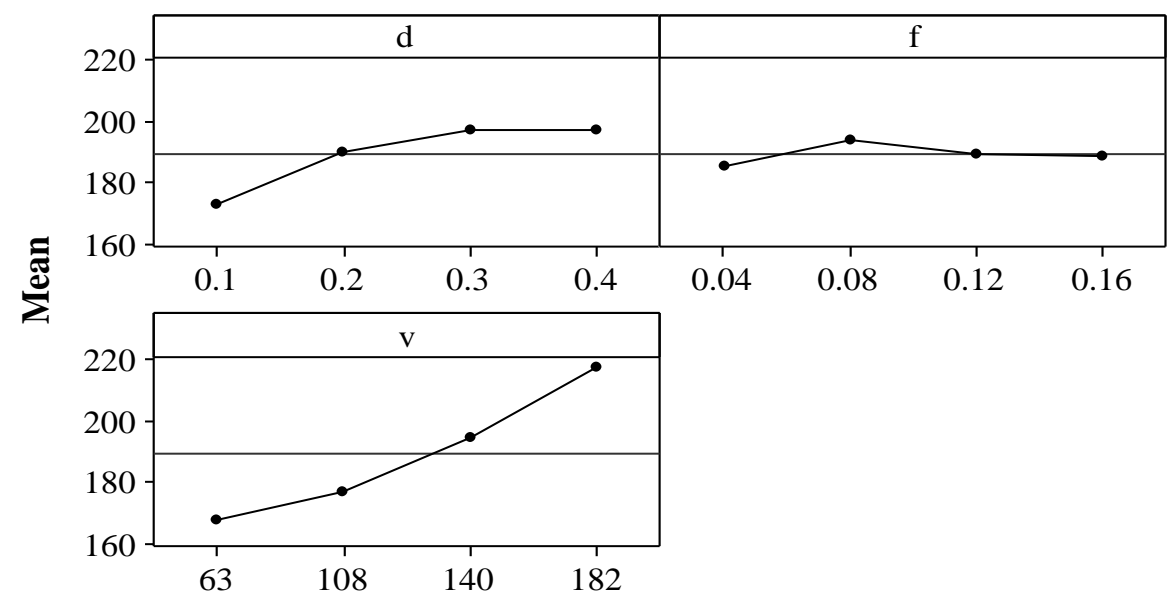

Figure 5. Graphical plot for cutting temperature.

\section{Aspects of Flank Wear}

Tool wear represents the sustainability of tool in cutting operations. The cutting tools gradually wear out due to high heat and high stress developed in machining. Gradual wear is classified in two ways namely crater wear and flank wear. Flank wear is considered for tool failure analysis based on recommended flank width limit of $0.3 \mathrm{~mm}$ [34 - 36].

Table 4. ANOVA for cutting temperature.

\begin{tabular}{|c|c|c|c|c|c|c|c|}
\hline Source & DF & Seq SS & Adj SS & Adj MS & $\mathrm{F}$ & $\mathrm{P}$ & Remarks \\
\hline $\mathrm{d}$ & 3 & 1608.54 & 1608.54 & 536.18 & 10.50 & 0.008 & Significant \\
\hline $\mathrm{f}$ & 3 & 134.68 & 134.68 & 44.89 & 0.88 & 0.503 & Insignificant \\
\hline $\mathrm{V}$ & 3 & 5891.20 & 5891.20 & 1963.73 & 38.46 & 0.000 & Significant \\
\hline Error & 6 & 306.37 & 306.37 & 51.06 & & & \\
\hline Total & 15 & 7940.80 & & \multirow{2}{*}{\multicolumn{3}{|c|}{$\mathrm{R}^{2}(\operatorname{adj})=90.35 \%$}} & \\
\hline \multicolumn{2}{|c|}{$S=7.14574$} & \multicolumn{2}{|c|}{$\mathrm{R}^{2}=96.14 \%$} & & & & \\
\hline
\end{tabular}

In the machining with spray cooling environment, the friction between tool-chip and tool work reduces and due to chemical reactions of cutting fluid, a lubricating film (thin) of low shear magnitude produce which causes to move chips easily from the tool surface. It favours less rate of growth of tool wear as shown in the result Table 2. From the results, it was identified that the flank wear width is lesser than $0.3 \mathrm{~mm}$ at smallest machining speed of $63 \mathrm{~m} / \mathrm{min}$ with depth of cut lies between 0.1 to $0.2 \mathrm{~mm}$ and feed lies from 0.04 to $0.08 \mathrm{~mm} / \mathrm{rev}$. In other cutting combinations, the wear width is noticed to be higher than $0.3 \mathrm{~mm}$. Abrasion in Figure 6 (a) is realized to the foremost wear mechanism at lower cutting speed, cutting feed and depth of cut, whereas diffusion and abrasion both are major wear mechanism recognized at higher cutting conditions. At the higher cutting speed identified that the chipping and catastrophic failure of cutting insert tip shown in 
Figure 6(b) to (d) respectively. Chipping of tool occurred due to lower toughness of tool, high stress, and shocks developed during cutting at elevated cutting speed, cutting feed and depth of cut. Catastrophic failure of tool occurred due to high thermal shock which is generated by higher heat, and high stress which is developed during machining with high machining speed, cutting feed and depth of cut. The above outcomes have been agreed with the review work reported by Chinchanikar and Choudhary [37].

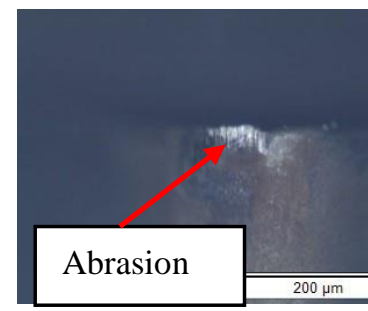

(a)

$d=0.1 \mathrm{~mm}$

$f=0.04 \mathrm{~mm} / \mathrm{rev}$

$v=63 \mathrm{~m} / \mathrm{min}$

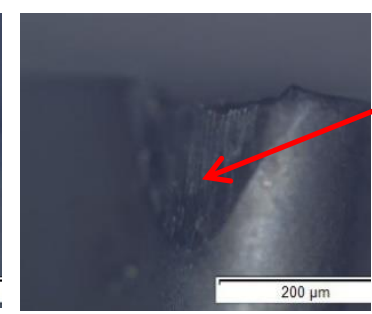

(b)

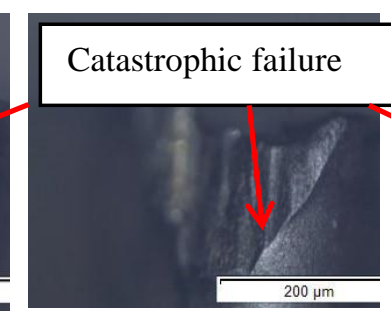

(c)

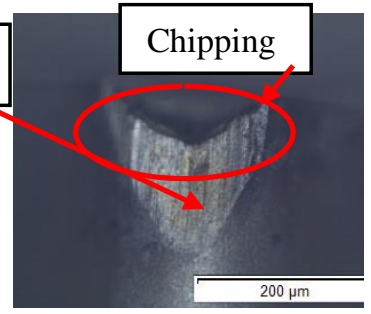

(d) $d=0.2 \mathrm{~mm}$
$f=0.16 \mathrm{~mm} / \mathrm{rev}$
$v=140 \mathrm{~m} / \mathrm{min}$

$d=0.3 \mathrm{~mm}$

$f=0.16 \mathrm{~mm} / \mathrm{rev}$

$v=108 \mathrm{~m} / \mathrm{min}$

Figure 6. Microscopic images of tool flank wear at (a) Run 1 (b) Run 4 (c) Run 8 (d) Run 12.

SEM with EDS analysis before and after machining for Run 7 is displayed in Figure 7 and Figure 8. From the EDS results, the carbon (C) element of cutting insert after machining increased by $68.19 \%$ by weight. The increment in carbon content after machining is happened due to diffusion of carbon content from high carbon workpiece (AISI D2 steel) to the tool-tip due to high chip-tool interface temperature generation $\left(214.2^{\circ} \mathrm{C}\right)$ at highest cutting speed $(182 \mathrm{~m} / \mathrm{min})$. Similarly, the oxygen $(\mathrm{O})$ content on tool tip is increased by $270 \%$ by weight or $100 \%$ by volume whereas iron (Fe) content is increased by $818 \%$ by weight or $391 \%$ by volume. Increment in \% oxygen on to the tool-tip is happened due to formation of oxidized layer on to the tool tip by impingement of water and air mixture coolant at interface of job-tool. Content of oxygen improved due to catastrophic breakage (due to high stress and temperature) of tool tip which exposed the internal portion of carbide tool more and there is chance of more concentration of oxygen element. Fe content is increased excessively due to macro diffusion by mass dissolution of iron from job to tool tip. Co content reduce by $66.7 \%$ by weight or $82 \%$ by weight due decomposition of Co on to the work surface or chip which reduced the bonding strength of uncoated carbide tool. Tungsten (W) content of tool is reduced by $75.8 \%$ by weight or $86.9 \%$ by volume due to higher loss of material from tool tip which occurred due to diffusion or catastrophic failure of tool tip.

\begin{tabular}{ccc}
\hline Element & \% Weight & \% Atomic \\
\hline C K & 26.82 & 69.98 \\
O K & 8.06 & 15.79 \\
Fe K & 0.83 & 0.47 \\
Co K & 7.76 & 4.13 \\
W M & 56.53 & 9.63 \\
Total & 100 & \\
\hline
\end{tabular}

(a)

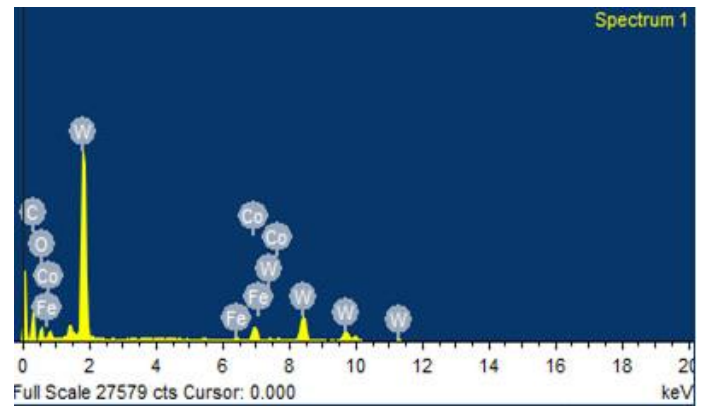

(b) 


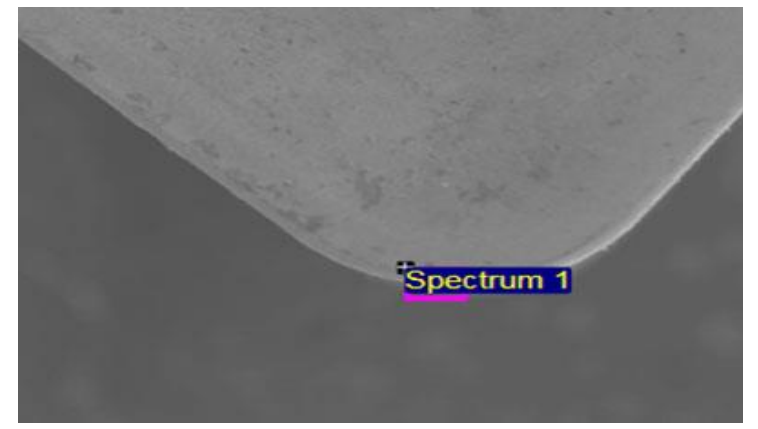

(c)

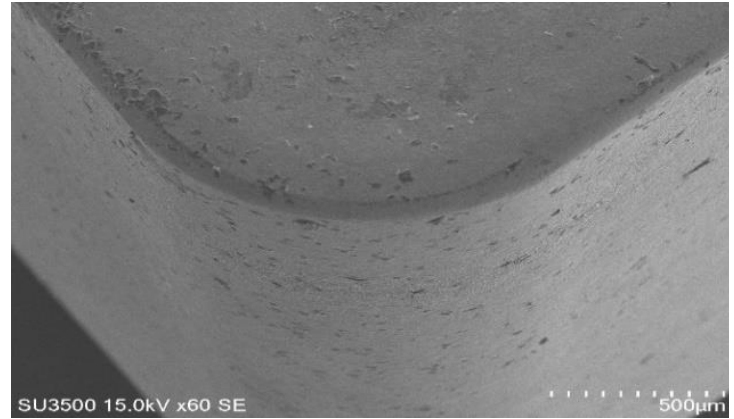

(d)

Figure 7. EDS (a) elemental composition and (b) spectrums with SEM micrograph of (c) tool tip of carbide insert and; (d) flank wear before machining for Run 7.

\begin{tabular}{ccc}
\hline Element & \% Weight & \% Atomic \\
\hline C K & 45.11 & 63.65 \\
O K & 29.84 & 31.62 \\
Fe K & 7.62 & 2.31 \\
Co K & 2.58 & 0.74 \\
Ti K & 1.17 & 0.42 \\
W M & 13.68 & 1.26 \\
Total & 100 & \\
\hline
\end{tabular}

(a)

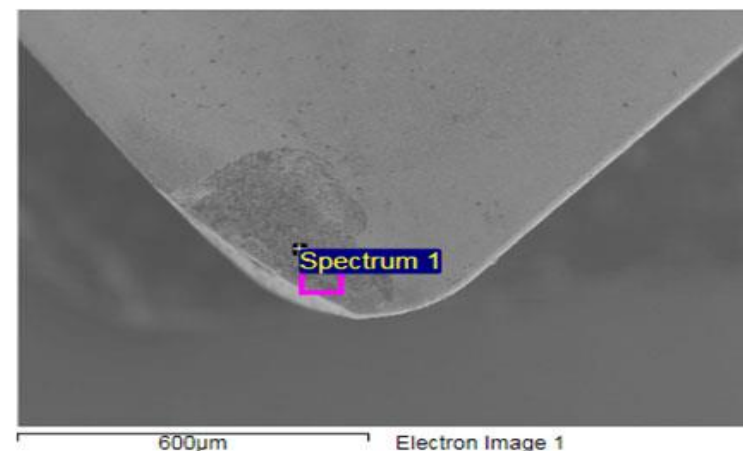

(c)

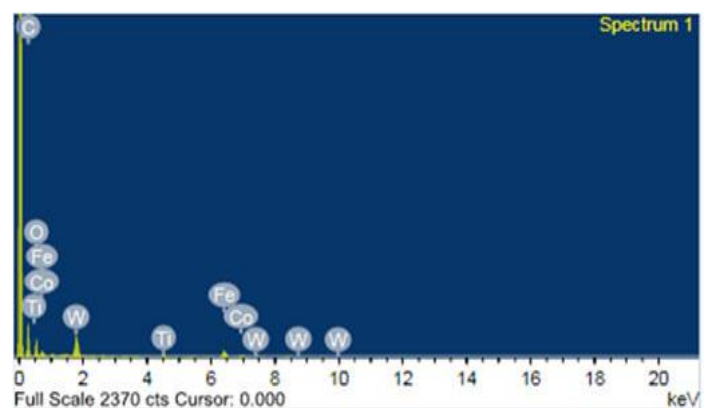

(b)

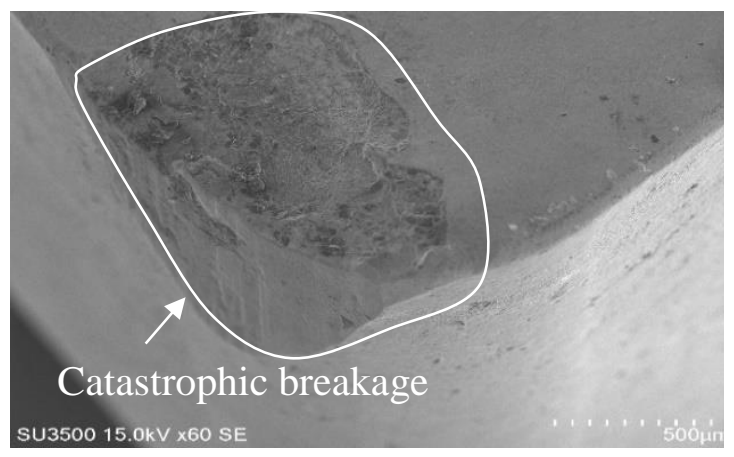

(d)

Figure 8. EDS (a) elemental composition and (b) spectrums with SEM micrograph of

(c) tool tip of carbide insert and; (d) flank wear after machining for Run 7.

From main effects graph in Figure 9, the nature of flank wear is increasing with rise in speed and depth of cut whereas influences of feed on flank wear are not significant as wear is almost steady with improving feed. ANOVA results in Table 5 clearly presents that the p-value (probability of significance) for machining speed and depth of cut are lower than 0.05 (confidence level $95 \%$ ). Hence, both machining speed and depth of cut parameters are declared as significant for flank wear whereas feed is insignificant as their $\mathrm{p}$ value is more than the 0.05 . Similar results reported by Ferreira et al. [38] as it was mentioned that the flank wear was greatly ruled by cutting speed during turning operation of $\mathrm{H} 13$ grade steel. 
Fitted Means

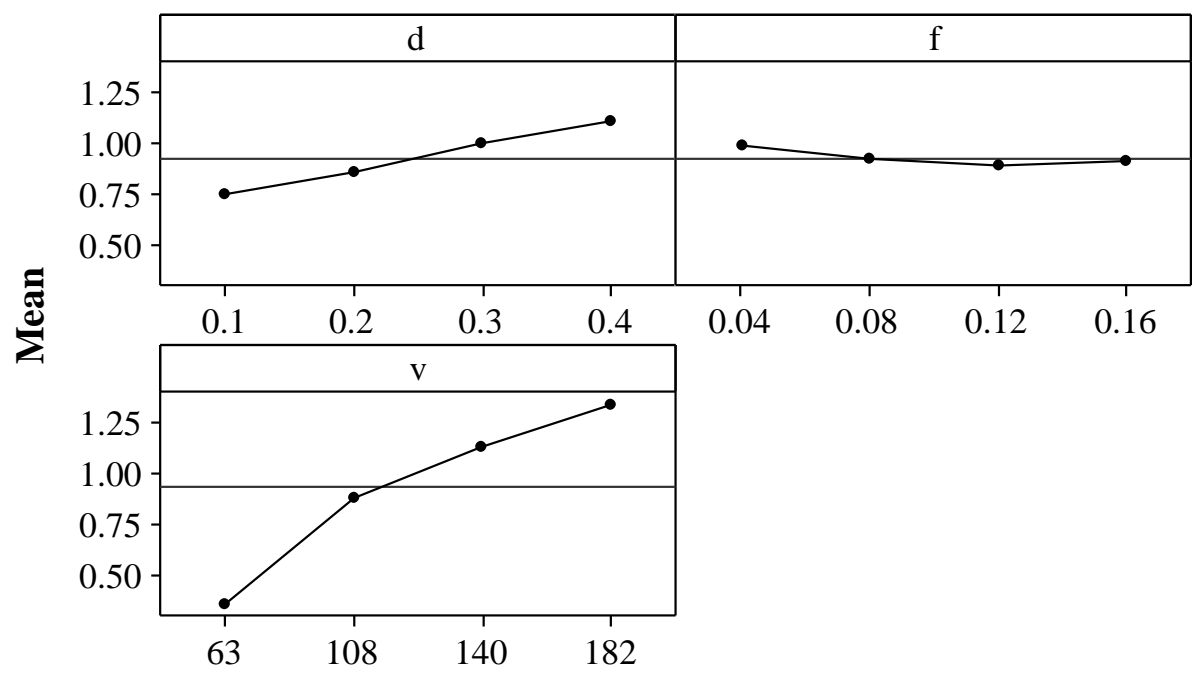

Figure 9. Graphical plot for flank wear.

\section{Aspects of Chip Morphology}

In the present work the shape of chips produced are either helical as in Figure 10(a) or ribbon as in Figure 10(b) or spiral $\mathrm{c}$ and $\varepsilon$ type as in Figure 10(c) or long snarl as in Figure 10(d). Helical shape chips easily removed from cutting zone and reduce friction, however, temperature reduces whereas ribbon, spiral, and long snarl may be tangle between work and tool surfaces and improves friction and temperature improves significantly. Referring to Table 2, the chips colour has been found either metallic or partial blue or blue or burnt blue. In most of experimental run due to spray impingement at cutting zone, the heated chip gets quenched and the chips colour changes to partial blue (incomplete quenching) or blue or burnt blue. In each test run, saw tooth (Table 2) chips are noticed. Saw tooth formation of chip occurred due to large micro cracks formed in compressive zone. When the compressive strength is enough to shear out the chip along the tool face, at that time micro-cracks is delocalise and distributed along the length of chip and look like a saw tooth.

Table 5. ANOVA for flank wear.

\begin{tabular}{lccccccc}
\hline Source & DF & Seq SS & Adj SS & Adj MS & F & P & Remarks \\
\hline $\mathrm{d}$ & 3 & 0.31516 & 0.31516 & 0.10505 & 9.49 & 0.011 & Significant \\
$\mathrm{f}$ & 3 & 0.02311 & 0.02311 & 0.00770 & 0.70 & 0.588 & Insignificant \\
v & 3 & 2.18776 & 2.18776 & 0.72925 & 65.86 & 0.000 & Significant \\
Error & 6 & 0.06644 & 0.06644 & 0.01107 & & & \\
Total & 15 & 2.59246 & & & & & \\
\multicolumn{7}{l}{$\mathrm{S}=0.105231$} & \multicolumn{2}{c}{$\mathrm{R}^{2}=97.44 \%$} & $\mathrm{R}^{2}(\operatorname{adj})=93.59 \%$ & \\
\hline
\end{tabular}




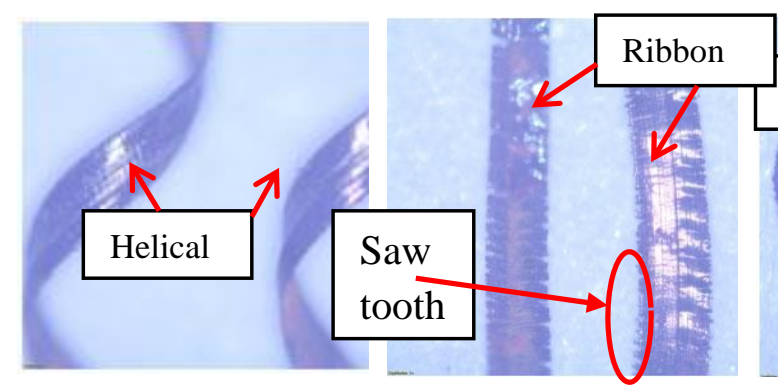

(a)

$d=0.1 \mathrm{~mm}$

$f=0.04 \mathrm{~mm} / \mathrm{rev}$

$v=108 \mathrm{~m} / \mathrm{min}$ (b)

$$
\begin{aligned}
& d=0.1 \mathrm{~mm} \\
& f=0.12 \mathrm{~mm} / \mathrm{rev} \\
& v=140 \mathrm{~m} / \mathrm{min}
\end{aligned}
$$

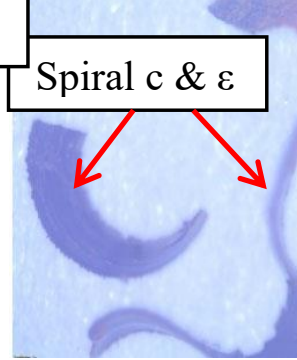

(c)

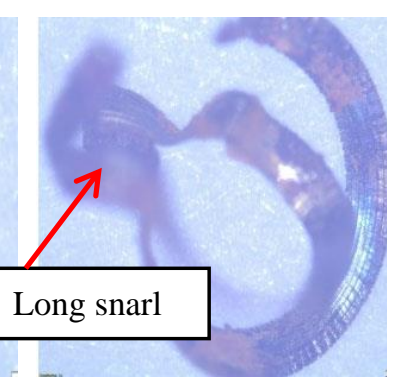

(d)

$$
\begin{array}{ll}
d=0.2 \mathrm{~mm} & d=0.3 \mathrm{~mm} \\
f=0.16 \mathrm{~mm} / \mathrm{rev} & f=0.08 \mathrm{~mm} / \mathrm{rev} \\
v=140 \mathrm{~m} / \mathrm{min} & v=182 \mathrm{~m} / \mathrm{min}
\end{array}
$$

Figure 10. Types of chip produced in hard turning at (a) Run 1, (b) Run 3, (c) Run 8 and; (d) Run 10.

\section{Chip Reduction Coefficient}

Chip reduction coefficient (CRC) plays a key role for machinability point of view as it qualitative investigate the power utilized as well as specific energy used in cutting actions. Lower is the CRC, better is the machinability. The mathematical expression for calculation of CRC is presented in Eq. (1).

Chip reduction coefficient $(\mathrm{CRC})=\mathrm{t}_{\mathrm{a}} / \mathrm{t}_{\mathrm{b}}=\mathrm{t}_{\mathrm{a}} /(\mathrm{f} . \operatorname{Sin} \phi)$

where, $t_{a}$ represents chip thickness after machining, $t_{b}$ represents chip thickness before machining, $f$ represents cutting feed and $\phi$ represents approach angle.

The chip reduction coefficient has been calculated using Eq. (1) and listed in Table 2. From main effects graph Figure 11, it can be reassured that the chip reduction coefficient gets improve with rising in depth of cut and reduces with improving machining speed and feed rate. From ANOVA Table 6, It is evident that all the three factors: depth of cut, feed and machining speed are the significant for CRC whereas the radial feed rate and depth of cut are the most dominating variable for CRC succeeded by cutting feed.

Overall, better quality of surface finish $(\mathrm{Ra} \leq 1.6 \mu \mathrm{m})$ is obtained during hard turning of AISI D2 steel (55 \pm 1 HRC) except that the highest feed $(0.16 \mathrm{~mm} / \mathrm{rev})$ with highest depth of cut $(0.4 \mathrm{~mm})$ and lowest machining speed $(63 \mathrm{~m} / \mathrm{min})$ cutting condition. The use of spray cooling system is competent enough for minimising the cutting temperature at chip-tool interface and induced favourable machining. Abrasion mode of tool failure is dominant at smaller range of cutting speed $(63 \mathrm{~m} / \mathrm{min})$ whereas diffusion and abrasion both are main wear mechanism recognised at the higher cutting conditions. 
Fitted Means

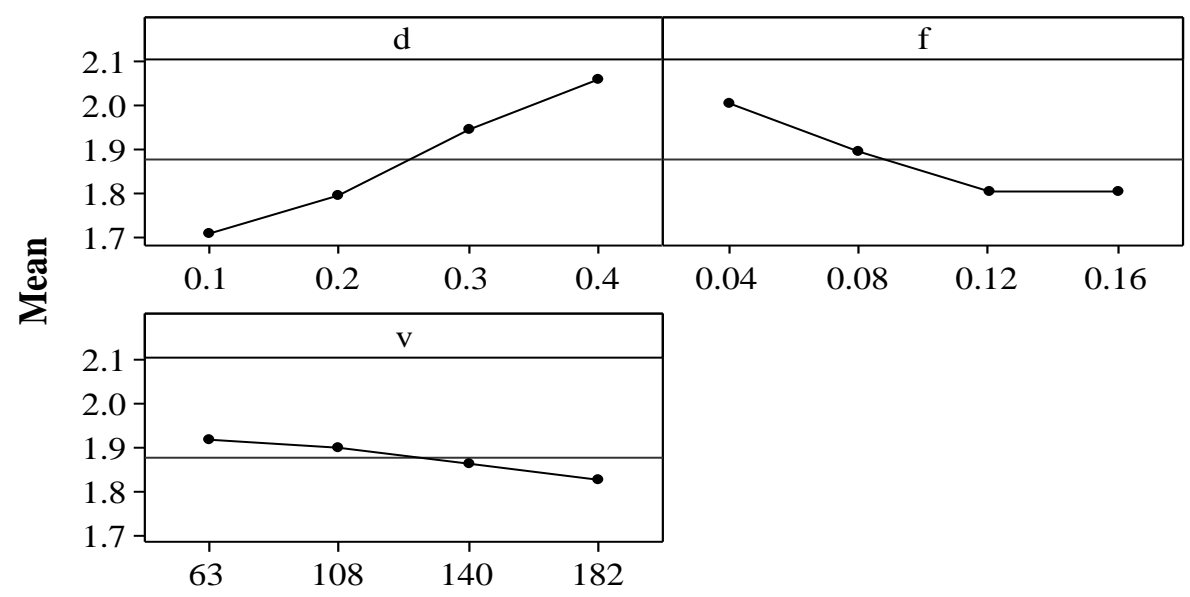

Figure 11. Graphical plot for chip reduction coefficient.

Table 6. ANOVA for chip reduction coefficient.

\begin{tabular}{lccccccc}
\hline Source & DF & Seq SS & Adj SS & Adj MS & F & P & Remarks \\
\hline $\mathrm{d}$ & 3 & 0.299265 & 0.299265 & 0.099755 & 144.52 & 0.000 & Significant \\
$\mathrm{f}$ & 3 & 0.110710 & 0.110710 & 0.036903 & 53.46 & 0.000 & Significant \\
$\mathrm{v}$ & 3 & 0.020199 & 0.020199 & 0.006733 & 9.75 & 0.010 & Significant \\
Error & 6 & 0.004141 & 0.004141 & 0.000690 & & & \\
Total & 15 & 0.434316 & & & & & \\
$\mathrm{~S}=0.0262726$ & $\mathrm{R}^{2}=99.05 \%$ & $\mathrm{R}^{2}(\operatorname{adj})=97.62 \%$ & & & \\
\hline
\end{tabular}

\section{MATHEMATICAL MACHINABILITY MODELS}

Nowadays mathematical models work as a powerful tool to correlate the machining outputs with input variables. In the present work, a quadratic mathematical expression has been formulated to establish a correlation between output responses (surface roughness $\mathrm{Ra}$; machining temperature $\mathrm{T}$; and flank wear $\mathrm{VBc}$ ) and input cutting variables (machining speed $v$; feed $f$; and depth of cut $d$ ) using regression analysis with 0.95 confidence level [39]. The mathematical correlation expressions are reported in Eq. (2) to (4). The developed models through quadratic regression for $\mathrm{Ra}, \mathrm{T}$ and $\mathrm{VBc}$ have higher value of determination coefficients ( $R 2$ value) showing significance of model as it approaches to one. From Figure 12, the experimental and fitted data for Ra, T and VBc are very close to each other which confirm the well fitness of model.

$\mathrm{Ra}=0.5118+0.5948 d+1.1079 f-0.0021 v+1.8000 d^{2}+50.6250 f^{2}-9.9493 d f+$

$0.0054 d v-0.0214 f v$;

$\mathrm{T}=91.36+405.57 d+724.64 f-0.23 v-443.75 d^{2}-1406.25 f^{2}-1397.50 d f+0.24 d v$

$-0.52 f v$;

$\mathrm{VBc}=-1.0569-0.0691 d+3.6746 f+0.0211 v-0.0375 d^{2}+13.9844 f^{2}-$

$3.7247 d f+0.0089 d v-0.0442 f v$; 


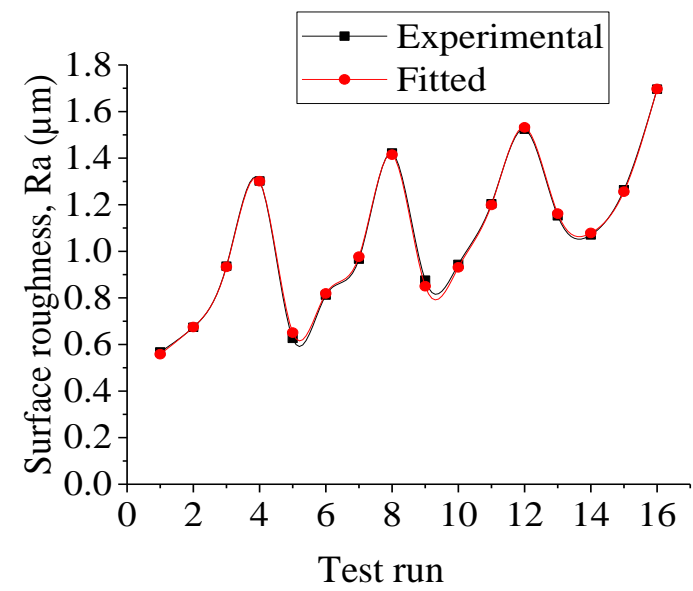

(a)

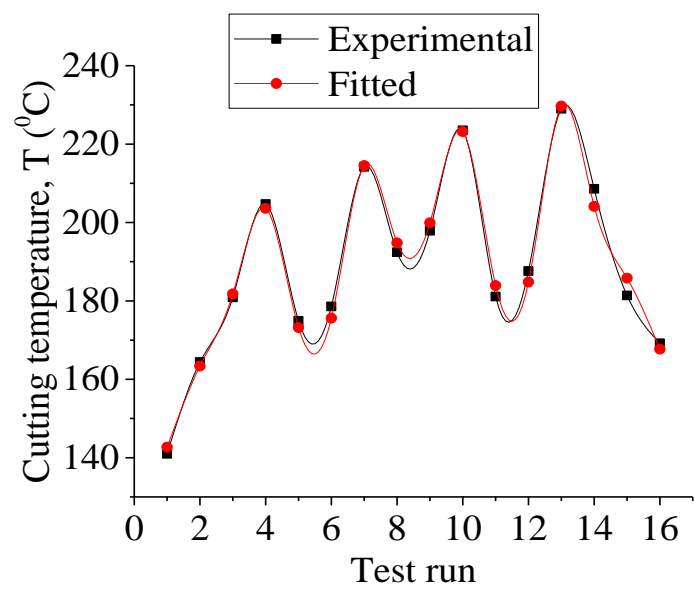

(c)

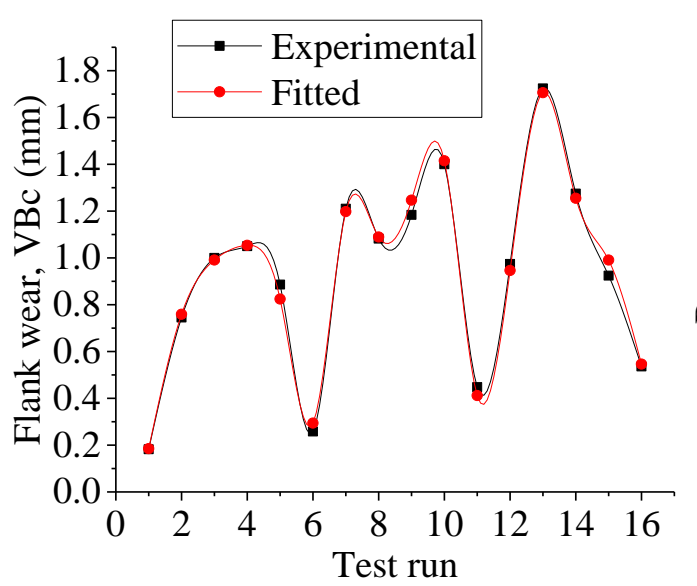

(e)

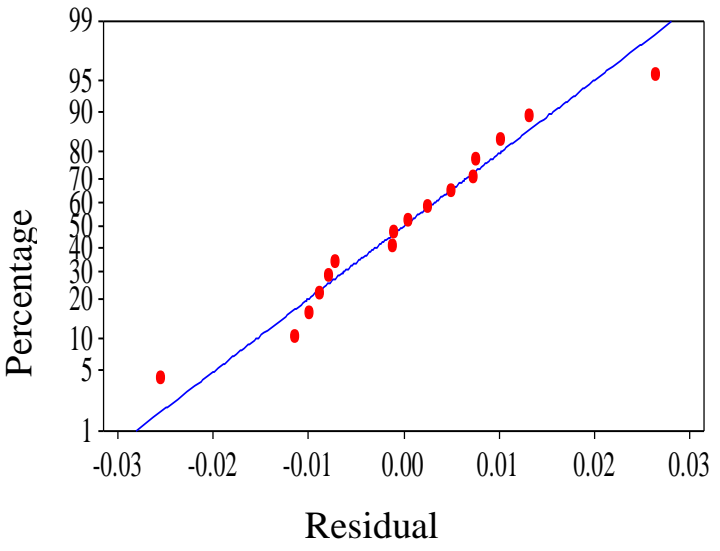

(b)

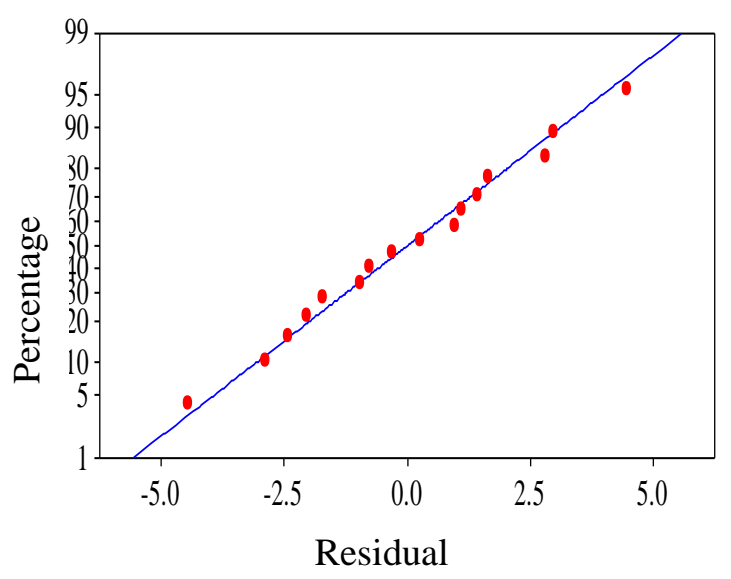

(d)

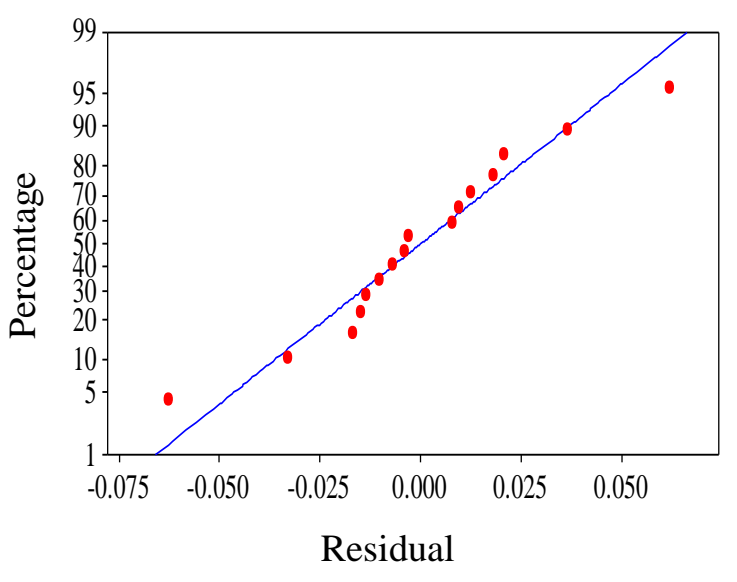

(f)

Figure 12. Experimental vs. fitted and normal probability plot of (a), (b) surface roughness, (c), (d) cutting temperature and; (e), (f) flank wear.

The normal probability plot for Ra, T and VBc in respective Figure 12(b), (d) and (f) indicates data are closely scattered to the straight line which ensures that the developed 
statistical models are significant. ANOVA results in Tables 7 to Table 9 indicate statistically significance where P-value is lower than 0.05 at $95 \%$ confidence level. That reveals fit models and can be effectively implemented in hard turning applications.

Table 7. ANOVA for surface roughness model.

\begin{tabular}{lccccccc}
\hline Source & DF & Seq SS & Adj SS & Adj MS & F & P & Remarks \\
\hline Regression & 9 & 1.59021 & 1.59021 & 0.176690 & 484.12 & 0.000 & Significant \\
Linear & 3 & 1.44743 & 0.00418 & 0.001393 & 3.82 & 0.077 & \\
Square & 3 & 0.11440 & 0.11394 & 0.037980 & 104.06 & 0.000 & \\
Interaction & 3 & 0.02837 & 0.02837 & 0.009457 & 25.91 & 0.001 & \\
Residual & 6 & 0.00219 & 0.00219 & 0.000365 & & & \\
error & & & & & & & \\
& 15 & 1.59240 & & & & & \\
Total & 15 & & & & & & \\
\hline
\end{tabular}

Table 8. ANOVA for temperature model.

\begin{tabular}{lccccccc}
\hline Source & DF & Seq SS & Adj SS & Adj MS & F & P & Remarks \\
\hline Regression & 9 & 7854.70 & 7854.70 & 872.744 & 60.82 & 0.000 & Significant \\
Linear & 3 & 6939.19 & 793.04 & 264.345 & 18.42 & 0.002 & \\
Square & 3 & 612.46 & 597.60 & 199.200 & 13.88 & 0.004 & \\
Interaction & 3 & 303.05 & 303.05 & 101.018 & 7.04 & 0.022 & \\
Residual & 6 & 86.10 & 86.10 & 14.350 & & & \\
error & & & & & & & \\
Total & 15 & 7940.80 & & & & & \\
\hline
\end{tabular}

Table 9. ANOVA for flank wear model.

\begin{tabular}{lccccccc}
\hline Source & DF & Seq SS & Adj SS & Adj MS & F & P & Remarks \\
\hline Regression & 9 & 2.58034 & 2.58034 & 0.286705 & 141.93 & 0.000 & Significant \\
Linear & 3 & 2.43257 & 0.19613 & 0.065376 & 32.36 & 0.000 & \\
Square & 3 & 0.09263 & 0.09334 & 0.031113 & 15.40 & 0.003 & \\
Interaction & 3 & 0.05515 & 0.05515 & 0.018383 & 9.10 & 0.012 & \\
Residual & 6 & 0.01212 & 0.01212 & 0.002020 & & & \\
error & & & & & & & \\
& 15 & 2.59246 & & & & & \\
Total & & & & & & & \\
\hline
\end{tabular}

\section{OPTIMISATION, TOOL LIFE AND COST ANALYSIS}

In the present work, Taguchi based grey relational analysis approach has been used for parametric optimisation of multi responses [40]. Lower is a better criterion selected for $\mathrm{Ra}, \mathrm{T}$ and $\mathrm{VBc}$. Taguchi $\mathrm{L}_{16}$ is utilized for performing the experiments and the results are reported in Table 2. Grey relation coefficient with equal weightage $(\psi=0.5)$, grey relational grade (GRG) and their rank are calculated presented in Table 10.

In this way, grey relational grade termed as renovate the multi response problem into single response. Mean grey relational grade of responses is reported in Table 11. 
From the mean grey relational table, higher mean grey relational value denotes the optimal level of parameters. From Table 11, the optimum cutting combination for uncoated carbide insert is $d 1-f 1-v 1$ i.e. depth of cut $=0.1 \mathrm{~mm}$, feed $=0.04 \mathrm{~mm} / \mathrm{rev}$ and machining speed $=63 \mathrm{~m} / \mathrm{min}$. The confirmation experiment has been performed between initial parameter setting with optimal parameter setting as presented in Table 12. The improvements of grey relational grade have been achieved to be 0.555 and are greatly improved.

Table 10. Estimation of $\triangle o i, G R C, G R G$ for uncoated carbide insert.

\begin{tabular}{cccccccc}
\hline \multicolumn{3}{c}{ Calculation of $\Delta_{\mathrm{oi}}$} & \multicolumn{2}{c}{ Calculation of GRC using $\psi=0.5$} & & \\
\cline { 6 - 8 } $\mathrm{Ra}$ & $\mathrm{T}$ & $\mathrm{VBc}$ & $\mathrm{Ra}$ & $\mathrm{T}$ & $\mathrm{VBc}$ & GRG & Rank \\
\hline 0.000 & 0.000 & 0.000 & 1.000 & 1.000 & 1.000 & & \\
0.094 & 0.266 & 0.365 & 0.842 & 0.653 & 0.578 & 1.000 & 1 \\
0.326 & 0.453 & 0.530 & 0.605 & 0.524 & 0.485 & 0.691 & 3 \\
0.651 & 0.724 & 0.563 & 0.435 & 0.409 & 0.470 & 0.538 & 7 \\
0.051 & 0.385 & 0.457 & 0.907 & 0.565 & 0.523 & 0.438 & 15 \\
0.216 & 0.427 & 0.049 & 0.698 & 0.539 & 0.910 & 0.665 & 4 \\
0.353 & 0.832 & 0.667 & 0.586 & 0.375 & 0.429 & 0.716 & 2 \\
0.757 & 0.584 & 0.584 & 0.398 & 0.461 & 0.461 & 0.463 & 10 \\
0.273 & 0.647 & 0.650 & 0.647 & 0.436 & 0.435 & 0.440 & 14 \\
0.333 & 0.938 & 0.790 & 0.600 & 0.348 & 0.388 & 0.506 & 8 \\
0.564 & 0.456 & 0.173 & 0.470 & 0.523 & 0.743 & 0.445 & 13 \\
0.848 & 0.530 & 0.514 & 0.371 & 0.486 & 0.493 & 0.579 & 5 \\
0.518 & 1.000 & 1.000 & 0.491 & 0.333 & 0.333 & 0.450 & 11 \\
0.445 & 0.768 & 0.709 & 0.529 & 0.394 & 0.414 & 0.386 & 16 \\
0.617 & 0.459 & 0.481 & 0.448 & 0.521 & 0.510 & 0.446 & 12 \\
1.000 & 0.320 & 0.230 & 0.333 & 0.609 & 0.685 & 0.493 & 9 \\
0.000 & 0.000 & 0.000 & 1.000 & 1.000 & 1.000 & 0.543 & 6 \\
\hline
\end{tabular}

Table 11. Mean grey relational grade of response for uncoated insert.

\begin{tabular}{ccccccc}
\hline \multirow{2}{*}{ Factors } & \multicolumn{3}{c}{ Mean grey relational grade } & Max-Min & \multirow{2}{*}{ Rank } \\
\cline { 2 - 5 } & Level1 & Level2 & Level3 & Level4 & & \\
\hline$d$ & 0.667 & 0.571 & 0.495 & 0.467 & 0.200 & 2 \\
$f$ & 0.639 & 0.574 & 0.518 & 0.468 & 0.171 & 1 \\
$v$ & 0.709 & 0.575 & 0.482 & 0.433 & 0.276 & 3 \\
\hline
\end{tabular}

Table 12. Confirmation test.

\begin{tabular}{|c|c|c|}
\hline & Initial parameter setting & Optimal parameter factors \\
\hline Level & $\mathrm{d} 3-\mathrm{f} 2-\mathrm{v} 4$ & d1-f1-v1 \\
\hline $\mathrm{Ra}(\mu \mathrm{m})$ & 0.944 & 0.568 \\
\hline $\mathrm{T}\left({ }^{\circ} \mathrm{C}\right)$ & 223.5 & 141 \\
\hline $\mathrm{VBc}(\mathrm{mm})$ & 1.4 & 0.182 \\
\hline Grey relational grade & 0.445 & 1 \\
\hline Improvement in GRG & \multicolumn{2}{|c|}{0.555} \\
\hline
\end{tabular}


The tool life of uncoated tool in spray impingement cooling surrounding has been calculated on the basis of $0.3 \mathrm{~mm}$ flank wear width criterion using optimal machining conditions ( $v=63 \mathrm{~m} / \mathrm{min}, f=0.04 \mathrm{~mm} / \mathrm{rev}$ and $d=0.1 \mathrm{~mm}$ ). Abrasion, notch wear and chipping types of wear mechanisms have been identified on flank surface as shown in Figure 13 (a). The surface roughness, chip-tool interface temperature, and flank wear width have been gradually improved with machining time as shown in Figures 14 (a) to (c) and the measured tool life is found 15 minutes whereas the corresponding temperature and surface roughness at tool life end condition is noticed to be $178.7^{\circ} \mathrm{C}$ as in Figure $13(\mathrm{~b})$, and $0.812 \mu \mathrm{m}$ respectively.

For manufacturing a product, the overall machining expenses are important relevant features in the metal machining industries. For the cost computation in machining operation required an effectual process planning. To minimizing the production cost of the product with low input cost is the principal objective of a manufacturing operation. In the machining process the operation cost, cutting tool cost, and the tool changing cost are the major constituents of total machining cost. Due to lesser tool life of cutting tool affixes to cost of tool changing and cutting tool cost because it covered re-sharpening as well as tool indexing costs. Tool life alters on tool wear and the tool wear is correlated with the cutting factors. So, for higher tool life, the process parameter should be chosen as smaller in magnitude but by choosing lower magnitude of cutting parameters, the productivity will decline. Hence, to sustain an appropriate balance among these disputing natures, a described economic study is vastly essential in hard machining [41, 42]. Gilbert's approach utilises to estimating the aggregate machining cost per cut are described in Eq. (5) to (9). In Stepl, the machining time per cut $\left(\mathrm{T}_{\mathrm{c}}\right)$ is given by:

$$
\mathrm{T}_{\mathrm{c}}=(\pi \mathrm{DL}) /(1000 \mathrm{vf})
$$

where, D implies diameter $(\mathrm{mm})$ of uncut specimen, $\mathrm{L}$ denotes machining length to be cut of workpiece $(\mathrm{mm})$, f denotes radial feed $(\mathrm{mm} / \mathrm{rev})$ and $\mathrm{v}$ denotes machining speed (m/min). In Step2, if ' $\mathrm{m}$ ' represents sum of cost associated for machine tool, spray cooling system, and operator with overhead, then machining cost in single cut is given by:

Machining cost in single cut $=\mathrm{m}_{\mathrm{c}}$
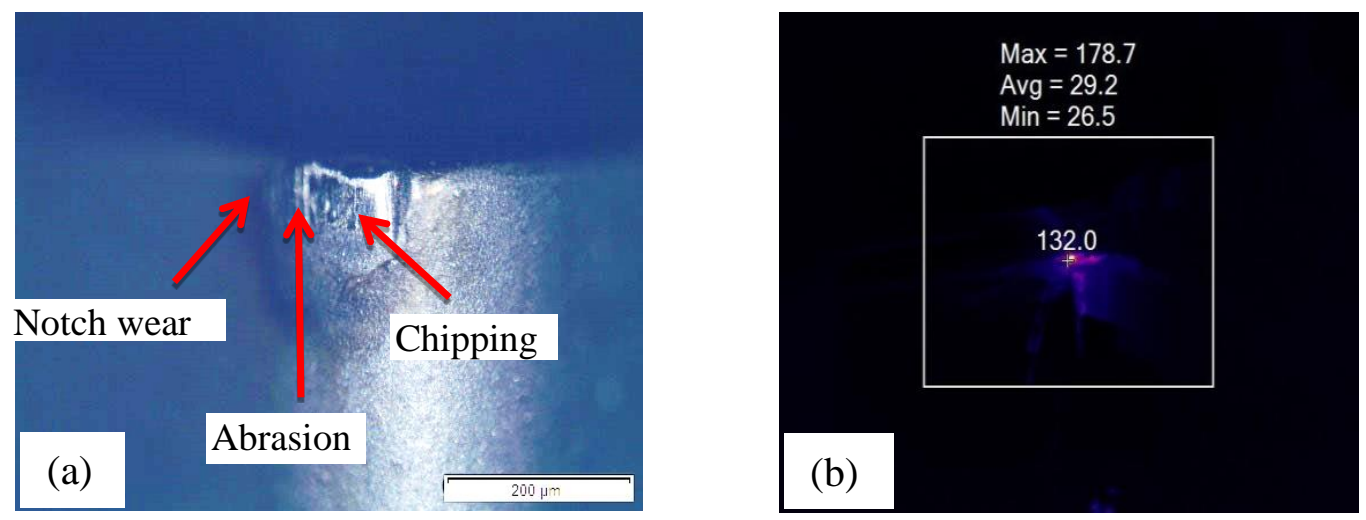

Figure 13. Images at end of tool life (a) flank wear and; (b) cutting temperature. 


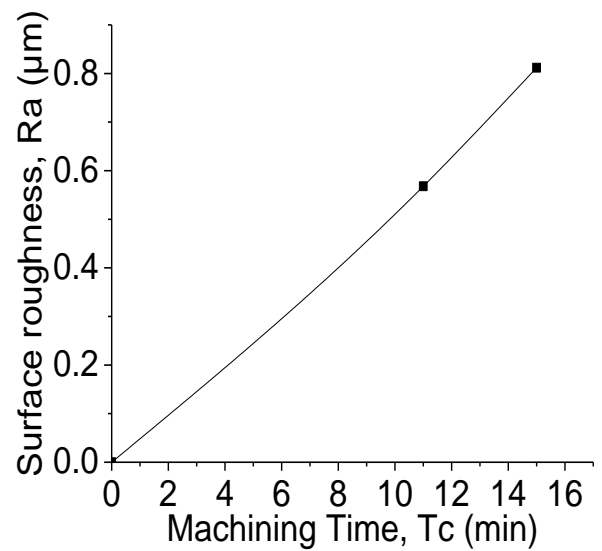

(a)

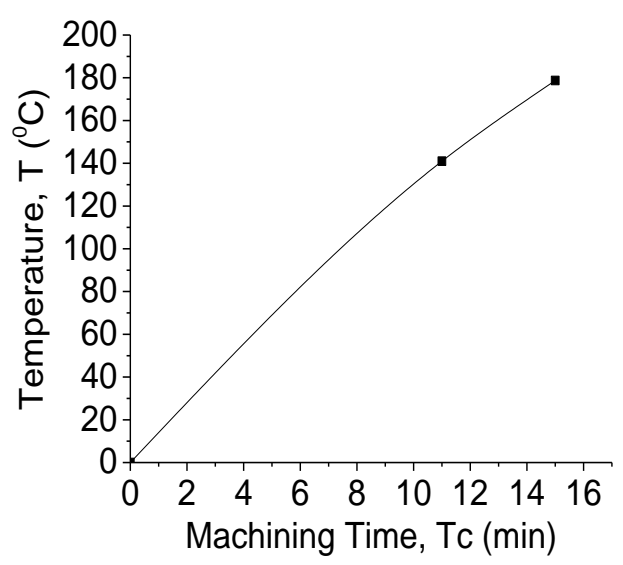

(b)

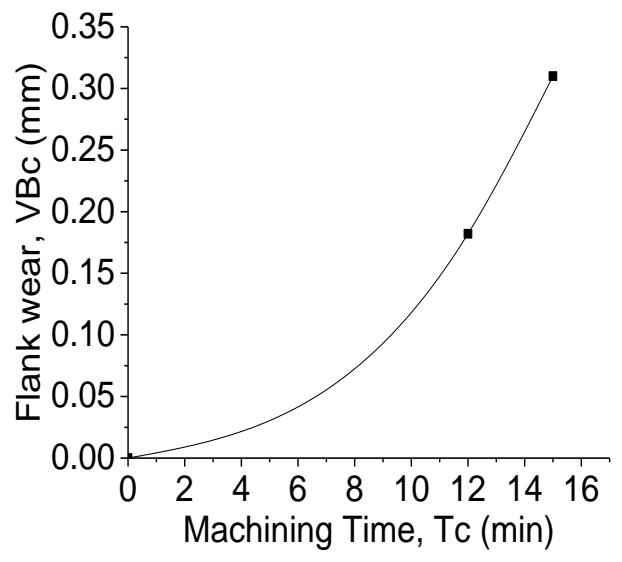

(c)

Figure 14. Variations of responses with machining time during tool life estimation (a) Ra vs. Tc (b) T vs. Tc and; (c) VBc vs. Tc.

In Step3, if $\mathrm{T}_{\mathrm{i}}$ is the idle time ( $\mathrm{min}$ ) to changing tool and $\mathrm{T}_{1}$ implies life of tool for one machining edge, then the tool changing cost in single cut:

Tool changing cost in single cut $=\mathrm{m} \mathrm{T}_{\mathrm{i}}\left(\mathrm{T}_{\mathrm{c}} / \mathrm{T}_{1}\right)$

In Step4, the machining tool cost in single cut:

Tool cost in single cut $=\mathrm{n}\left(\mathrm{T}_{\mathrm{c}} / \mathrm{T}_{1}\right)$

where ' $\mathrm{n}$ ' is the mean value of one machining tip. For Step5, the overall machining cost in single cut $(\mathrm{C})$ is the algebraic sum of machining cost, cutting tool changing cost and the cutting tool cost in single cut:

$\mathrm{C}=\mathrm{m} \mathrm{T}_{\mathrm{c}}+\mathrm{m} \mathrm{T}_{\mathrm{i}}\left(\mathrm{T}_{\mathrm{c}} / \mathrm{T}_{1}\right)+\mathrm{n}\left(\mathrm{T}_{\mathrm{c}} / \mathrm{T}_{1}\right)$

Tool life of the cutting tool at the optimum cutting conditions required to calculate the economical estimation of the cutting tool and its determined 15 minutes and total 
machining expenses at optimal condition show in Table 13. The cost in single cut has been calculated taking uncut diameter (D) of $40 \mathrm{~mm}$, cutting length (L) of $100 \mathrm{~mm}$, D2 grade steel work-piece (55 \pm 1 HRC) and at their optimum machining levels respectively. The overall cost of the machine tool and machinist (m) is consisting as Rs1000 (USD 15) per hour (at $16.67 \mathrm{~min}^{-1}$ ). The cost of uncoated carbide tool is Rs 210 (USD 3) per insert and every single insert consist of 4 working cutting tip. Hence, the average value of one cutting tip (n) is analysed to be Rs 53 (USD 0.75). The overall machining cost in single cut for uncoated carbide tool is calculated as Rs 128.3 (USD 1.90) and observed to be quite less.

Table 13. Total machining cost estimation for optimal turning variables ( $\mathrm{v}=63 \mathrm{~m} / \mathrm{min}$, $\mathrm{f}=0.04 \mathrm{~mm} / \mathrm{rev}, \mathrm{d}=0.1 \mathrm{~mm}), \mathrm{W} / \mathrm{P}=\mathrm{D} 2 \mathrm{steel}(\varnothing 40 \times 100 \mathrm{~mm})$, tool $=$ uncoated carbide,

$\mathrm{VBc}=0.3 \mathrm{~mm}, \mathrm{~T}_{\mathrm{i}}=5 \mathrm{~min}$.

\begin{tabular}{lll}
\hline S.No. & Type of cost & Uncoated carbide \\
\hline i & Cost of machine tool including spray cooling system & Rs 16.67 (USD 0.25) \\
ii & and operator $(\mathrm{m})$, Rs 1000 (USD 15) per hour & per min \\
iii & Machining time $\left(\mathrm{T}_{\mathrm{c}}\right)$ & $4.98 \mathrm{~min}$ \\
iv & Machining cost in single cut $\left(\mathrm{m}_{\mathrm{c}} \mathrm{T}_{\mathrm{c}}\right)$ & Rs 83.02 (USD 1.25) \\
v & Tool life (single tip) $\mathrm{T}_{1}$ & $15 \mathrm{~min}$ \\
vi & Tool changing cost in single cut [m $\left.\mathrm{T}_{\mathrm{i}}\left(\mathrm{T}_{\mathrm{c}} / \mathrm{T}_{1}\right)\right]$ & Rs 27.67 (USD 0.40) \\
vii & Mean cost of one cutting edge $(\mathrm{n})$ & Rs 53 (USD 0.75) \\
viii & Cutting tool cost in single cut $\left[\mathrm{n}\left(\mathrm{T}_{\mathrm{c}} / \mathrm{T}_{1}\right)\right]$ & Rs 17.6 (USD 0.25) \\
\hline
\end{tabular}

\section{CONCLUSION}

Research on hard turning performance of AISI D2 steel with the use of uncoated carbide insert during spray impingement cooling surrounding has been extensively investigated through machinability indices such as flank wear, surface roughness, machining temperature and chip morphology and subsequent approaches towards modelling, optimisation, tool life and cost analysis, following conclusions are drawn:

i. Arithmetic surface roughness value is found to be lower than the recommended roughness limit of 1.6 micron except at highest feed with highest depth of cut and lowest machining speed cutting condition. Feed rate and depth of cut are the most relevant factor for surface roughness.

ii. As the maximum machining temperature generated among all runs is $229^{\circ} \mathrm{C}$, thus the use of spray cooling system is competent enough for minimizing the cutting temperature at chip-tool interface and induced favourable machining. This may be due to the reduction of friction through capillary action of high pressure and high velocity fluid into cutting zone. Cutting speed is highly significant for cutting temperature succeeded by depth of cut.

iii. Abrasion is obtained to the major mechanism of wear at lower cutting parameters condition whereas diffusion and abrasion both are main wear mechanism recognized at higher cutting conditions. For wear at flank surface observed that machining speed and depth of cut are significant.

iv. In each test run, saw tooth chips are noticed. Saw tooth formation of chip occurred due to large micro cracks formed in compressive zone. Depth of cut and feed are the highest dominating variable for CRC succeeded by cutting feed. 
v. Optimum cutting combination for uncoated carbide insert is found to be $d 1-f 1-v 1$ i.e. depth of cut $=0.1 \mathrm{~mm}$, feed $=0.04 \mathrm{~mm} / \mathrm{rev}$ and machining speed $=63 \mathrm{~m} / \mathrm{min}$. The improvements of grey relational grade have been found to be 0.555 and are greatly improved.

vi. The developed models through quadratic regression for $\mathrm{Ra}, \mathrm{T}$, and $\mathrm{VBc}$ have higher value of determination coefficients $\left(\mathrm{R}^{2}\right.$ value) revealing significance of model as it approaches to one. The predicted and experimental values are nearly to each other.

vii. Surface roughness, chip-tool contact temperature and flank wear width have been gradually improved with machining time and the measured tool life is found as about 15 minutes at optimal cutting conditions whereas the corresponding temperature and at the end of tool life surface roughness is noticed to be $178.7^{\circ} \mathrm{C}$ and $0.812 \mu \mathrm{m}$. Abrasion, notch wear and chipping types of wear mechanisms have been identified on flank surface. Thus, the optimised parameters may be utilized in hard turning without frequent changing of inserts.

viii. As the total machining cost is less (Rs.128.3 or USD 1.90), it can be justified that the uncoated tool can be capable of machining hardened AISI D2 steel effectively, efficiently and economically at optimum cutting conditions under spray impingement cooling environment.

\section{ACKNOWLEDGEMENT}

The authors express thank to Kalinga Institute of Industrial Technology (KIIT), Deemed to be University, Bhubaneswar, Odisha India and VSSUT Burla for offering the facilities to conduct the research work.

\section{REFERENCES}

[1] Liew PJ, Shaaroni A, Sidik NAC. Yan, J. An overview of current status of cutting fluids and cooling techniques of turning hard steel. International Journal of Heat and Mass Transfer. 2017; 114:380-394.

[2] Sahu SK, Mishra PC, Orra K, Sahoo AK. Performance assessment in hard turning of AISI 1015 steel under spray impingement cooling and dry environment. Proc. IMechE Part B: Journal of Engineering Manufacture. 2015; 229 (2): 251-265.

[3] Mishra PC, Das DK, Ukamanal M, Routara BC, Sahoo AK. Multi-response optimisation of process parameters using Taguchi method and grey relational analysis during turning AA $7075 / \mathrm{SiC}$ composite in dry and spray cooling environments. International Journal of Industrial Engineering Computations. 2015; 6: 445-456.

[4] Sahoo AK, Sahoo B. Performance studies of multilayer hard surface coatings (TiN/TiCN/Al ${ }_{2} \mathrm{O}_{3} / \mathrm{TiN}$ ) of indexable carbide inserts in hard machining: Part-I (An experimental approach). Measurement. 2013; 46:2854-2867.

[5] Tang L, Huang J, Xie L. Finite element modeling and simulation in dry hard orthogonal cutting AISI D2 tool steel with CBN cutting tool. International Journal of Advanced Manufacturing Technology. 2011; 53:1167-1181.

[6] Sahoo AK, Sahoo B. A comparative study on performance of multilayer coated and uncoated carbide inserts when turning AISI D2 steel under dry environment. Measurement. 2013; 46:2695-2704. 
[7] Mia M, Dhar NR. Optimisation of surface roughness and cutting temperature in high-pressure coolant-assisted hard turning using Taguchi method. International Journal of Advanced Manufacturing Technology. 2017; 88:739-753.

[8] Gnanadurai RR, Varadarajan AS. Investigation on the effect of cooling of the tool using heat pipe during hard turning with minimal fluid application. Engineering Science and Technology, an International Journal. 2016; 19:11901198.

[9] Kurnosov NE, Lebedinskiy KV, Tarnopolskiy AV, Asoskov AS, Perelygin YP. Turning of structural steel while supplying cooled ionized air to the cutting zone. Australian Journal of Mechanical Engineering. 2018; 16: 58-64.

[10] Sharma J, Sidhu BS. Investigation of effects of dry and near dry machining on AISI D2 steel using vegetable oil. Journal of Cleaner Production. 2014; 66:619623.

[11] Agrawala A, Goel S, Rashid WB, Price M. Prediction of surface roughness during hard turning of AISI 4340 steel (69 HRC). Applied Soft Computing. 2015; 30:279-286.

[12] Bouacha K, Yallese MA, Khamel S, Belhadi S. Analysis and optimisation of hard turning operation using cubic boron nitride tool. International Journal of Refractory Metals and Hard Materials. 2014; 45:160-178.

[13] Bartarya G, Choudhury SK. Influence of machining parameters on forces and surface roughness during finish hard turning of EN 31 steel. Proc. IMechE, Part B: Journal of Engineering Manufacture. 2013; 228(9):1068-1080.

[14] Aouici H, Yallese MA, Chaoui K, Mabrouki T, Rigal JF. Analysis of surface roughness and cutting force components in hard turning with $\mathrm{CBN}$ tool: Prediction model and cutting conditions optimisation. Measurement. 2012; 45:344-353.

[15] Khamel S, Ouelaa N, Bouacha K. Analysis and prediction of tool wear, surface roughness and cutting forces inhard turning with $\mathrm{CBN}$ tool. Journal of Mechanical Science and Technology. 2012; 26(11):3605-3616.

[16] Aouici H, Yallese MA, Fnides B, Chaoui K, Mabrouki T. Modeling and optimisation of hard turning of X38CrMoV5-1 steel with CBN tool: Machining parameters effects on flank wear and surface roughness. Journal of Mechanical Science and Technology. 2011; 25(11):2843-2851.

[17] Bouacha K, Yallese MA, Mabrouki T, Rigal JF. Statistical analysis of surface roughness and cutting forces using response surface methodology in hard turning of AISI 52100 bearing steel with CBN tool. International Journal of Refractory Metals and Hard Materials. 2010; 28:349-361.

[18] Sahin Y. Comparison of tool life between ceramic and cubic boron nitride (CBN) cutting tools when machining hardened steels. Journal of Materials Processing Technology. 2009; 209:3478-3489.

[19] Rout A, Satapathy A, Mantry S, Sahoo A, Mohanty T. Erosion wear performance analysis of polyester-GF-granite hybrid composites using the Taguchi method. Procedia Engineering. 2012; 38:1863-1882.

[20] Dureja JS, Gupta VK, Sharma VS, Dogra M. Wear mechanisms of TiN-coated CBN tool during finish hard turning of hot tool die steel. Proc IMechE, Part B: Journal of Engineering Manufacture. 2009; 224:553-566.

[21] Yallese MA, Chaouib K, Zeghib N, Boulanouar L, Rigal JF. Hard machining of hardened bearing steel using cubic boron nitride tool. Journal of Materials Processing Technology. 2009; 209:1092-1104. 
[22] Kumar R, Sahoo AK, Satyanarayana K, Rao GV. Some studies on cutting force and temperature in machining Ti-6Al-4V alloy using regression analysis and ANOVA. International Journal of Industrial Engineering Computations. 2013; 4:427-436.

[23] Zinati RF, Razfar MR. Multi-objective constrained optimisation of turning process via modified harmony search algorithm. Iranian Journal of Science and Technology, Transactions of Mechanical Engineering. 2017; https://doi.org/10.1007/s40997-017-0118-9.

[24] Chinchanikar S, Choudhary SK. Investigations on machinability aspects of hardened AISI 4340 steel at different levels of hardness using coated carbide tools. International Journal of Refractory Metals and Hard Materials. 2013; 38:124-133.

[25] Shalaby MA, ElHakim MA, Abdelhameed MM, Krzanowski JE, Veldhuis SC, Dosbaeva GK. Wear mechanisms of several cutting tool materials in hard turning of high carbon-chromium tool steel. Tribology International. 2014; 70:148-154.

[26] Das A, Mukhopadhyay A, Patel SK, Biswal BB. Comparative Assessment of machinability aspects of AISI 4340 alloy steel using uncoated carbide and coated cermet inserts during hard turning. Arabian Journal for Science and Engineering 2016; 41:4531-4552.

[27] Jasni NAH, Lajis MA, Kamdani K. Tool wear performance of TiAlN/AlCrN multilayer coated carbide tool in machining of AISI D2 hardened steel. Advanced Materials Research. 2012; 488-489:462-467.

[28] Dosbaeva GK, ElHakim MA, Shalaby MA, Krzanowski JE, Veldhuis SC. Cutting temperature effect on PCBN and CVD coated carbide tools in hard turning of D2 tool steel. International Journal of Refractory Metals and Hard Materials. 2015; 50:1-8.

[29] Mhamdi MB, Salem SB, Boujelbene M, Bayraktar E. Experimental study of the chip morphology in turning hardened AISI D2 steel. Journal of Mechanical Science and Technology. 2013; 27(11):3451-3461.

[30] Najiha MS, Rahman MM. Experimental study on minimum quantity lubrication in end milling of AA 6061-t6 using TIALN coated carbide tools. International Journal of Automotive and Mechanical Engineering. 2015; 11:2771-2785.

[31] Sahid NSM, Rahman MM, Kadirgama K, Ramasamy D, Maleque MA, Noor MM. Experimental investigation on the performance of the $\mathrm{TiO}_{2}$ and $\mathrm{ZnO}$ hybrid nanocoolant in ethylene glycol mixture towards AA6061-T6 machining. International Journal of Automotive and Mechanical Engineering. 2017; 14(1):3913-3926.

[32] Gajrani KK, Suvin PS, Kailas SV, Sankar MR. Hard machining performance of indigenously developed green cutting fluid using flood cooling and minimum quantity cutting fluid, Journal of Cleaner Production. 2019; 206: 108-123.

Doi: 10.1016/j.jclepro.2018.09.178.

[33] Saedon JB. Micromilling of hardened (62 HRC) AISI D2 cold work tool steel. Doctor of philosophy thesis. The University of Birmingham UK. 2011.

[34] Bensouilah H, Aouici H, Meddour I, Yallese MA, Mabrouki T, Girardin F. Performance of coated and uncoated mixed ceramic tools in hard turning process. Measurement. 2016; 82: 1-18.

[35] Orra K, Choudhury SK. Development of flank wear model of cutting tool by using adaptive feedback linear control system on machining AISI D2 steel and AISI 4340 steel. Mechanical Systems and Signal Processing. 2016; 81: 475-492. 
[36] Yallese MA, Rigal JF, Chaoui K, Boulanouar L. The effects of cutting conditions on mixed ceramic and cubic boron nitride tool wear and on surface roughness during machining of X200Cr12 steel $(60 \mathrm{HRC})$. Proceedings of the Institution of Mechanical Engineers, Part B: Journal of Engineering Manufacture. 2006; 219(1): 35-55.

[37] Chinchanikar S, Choudhary SK. Machining of hardened steel-experimental investigations, performance modeling and cooling technique: A review. International Journal of Machine Tools and Manufacture. 2015; 89:95-109.

[38] Ferreira R, Rehor R, Lauro CH, Carou D, Davim JP. Analysis of the hard turning of AISI H13 steel with ceramic tools based on tool geometry: surface roughness, tool wear, and their relation. Journal of the Brazilian Society of Mechanical Sciences and Engineering. 2016; 38:2413-2420.

[39] Sahoo AK, Rout AK, Das DK. Response surface and artificial neural network prediction model and optimisation for surface roughness in machining. International Journal of Industrial engineering Computations. 2015; 6(2): 229240.

[40] Panda A, Sahoo AK, Panigarhi I, Rout AK. Investigating Machinability in Hard Turning of AISI 52100 Bearing Steel Through Performance Measurement: QR, ANN and GRA Study. International Journal of Automotive and Mechanical Engineering. 2018; 15(1):4935-4961.

[41] More AS, Jiang W, Brown WD, Malshe AP. Tool wear and machining performance of $\mathrm{cBN}-\mathrm{TiN}$ coated carbide inserts and PCBN compact inserts in turning AISI 4340 hardened steel. Journal of Materials Processing Technology. 2006; 180:253-262.

[42] Kumar R, Sahoo AK, Mishra PC, Das RK. Comparative study on machinability improvement in hard turning using coated and uncoated carbide inserts: part II modeling, multi-response optimisation, tool life, and economic aspects. Advances in Manufacturing. 2018; 6(2):155-175. 